Herger Csabáné

DOI: 10.15170/DIKE.2020.04.01.05

habilitált egyetemi docens

PTE ÁJK

\title{
Az egyházak és az állam közötti viszony modernizálásának modelljei Kajtár István emlékére
}

\section{Models of the Modernization of the Connection between Church and State. In memory of István Kajtár}

Honouring the memory of Istvan Kajtár, this paper reviews the English, American, French and German modernization models of the connection between Church and State. The reason bebind the historical comparative law method can be shown with a part from the speech of the Minister of Culture, Jóssef Eötvös given at the House of Representatives on 16th February, 1870: "When defining the connection between Church and State, only two systems can be followed in a constitutional country, where the equality principle is a starting point: either the State has equal impact on each confession or every confession is completely free. The first one was favoured by many and considered the only right and true constitutional system after the principles established in 1789 in France. The other one is the system of freedom, which can be seen in America and in Switzerland and which will root in such proportion as real freedom in every country of the world. There is either a state religion or oppressed religion, but in a constitutional state, both are impossible."

Keywords: modernization, church and state, comparative legal bistory

\section{A modernizáció-történeti kutatások Kajtár István életmüvében}

Szeretett és tisztelt professzorom, Kajtár István a pécsi jogi kar nagyívű előadásairól és emberségéről ismert fiatal docense volt 1990-ben, amikor egyetemi tanulmányaimat megkezdtem. Az 1992-93. tanévtől a demonstrátora voltam, majd 1995-től a tanársegédje. Személyiségének egyik központi eleme volt a világnézeti tolerancia, ami lehetôvé tette, hogy professzor és tanítványa közötti mindennapi, szoros együttmúködésben több mint két és fél évtizedet töltsünk el.

Arra buzdított, hogy az egyházak és az állam közötti viszony összehasonlító jogtörténeti vizsgálatával foglalkozzak: ennek eredménye volt, hogy 2006-ban a házassági köteléki jog szekularizációját feldolgozó doktori értekezésemet, majd 2011-ben a polgári állam és az egyházi autonómia témaköréből készített habilitációs írásomat védhettem meg. Mindkét terület illeszkedett modernizáció-történeti munkásságához, ami két tekintetben is fontos előnnyel járt: egyrészt táplálkoztam abból, amit ő már feldolgozott és rendszerbe foglalt, másrészt a számára végzett háttérkutatások eredményeit a saját munkámhoz is fel tudtam használni.

\footnotetext{
${ }^{1}$ ZELLER, A magyar egyházpolitika I. 629-634.
} 
Kajtár István szakirodalmi munkásságában - az özvegye által összeállított, tematikus bibliográfiát kézbe véve - szembetűnő, hogy hány évet és mekkora erőt fektetett a polgári állam és a polgári jogrendszer kialakulása és működése vizsgálatára. Először 1995-ben jelentkezett a tudományos szakmai közönség előtt e témában tanulmánnyal (Modernizációnk és Európa: Adalékook a politikai vitakultúrához az 1843-44-es rendi orsqággyülésen), melyet számos résztanulmány követett magyar és német nyelven (1996: A büntető igazságszolgáltatás modernizációja a XIX. sqáąadban; 1997: A magyar állam modernizációs folyamatai a XIX. században: kitekintéssel a XX. század elsó felére; 1997: Töredékek a XIX. századi magyar állam-és jogrendszer modernizációjához, 1998: $A$, konzervativ" és a ,modern" a XIX. századi magyar jogtörténetben; 1999: 184849 és a XIX. századi modernizáció; 2000: A dualista kori magyar állam-és jogrendszer a modernizáció fényében; 2000: Allam és jogfejlödés Magyarországon a 19. században; 2000: Modernisierung in Ungarnim 19. Jabrbundert und die Staatsfinanzen anhand rechtshistorischer Beispiele). 2000-ben készült el $A$ 19. századi modern magyar állam-és jogrendszer alapjai: Tradíció - Európa - recepció címú összegző műve is, amelyet az MTA doktori cím elnyerésére nyújtott be. Három évvel később szerete meg DSc fokozatát, amikor a múve már nyomtatásban is megjelent a Dialóg Campus Kiadó gondozásában.

A modernizáció kérdésének számos eleme azonban továbbra is foglalkoztatta (2001: Európai jogi kultúra - magyar modernizáció a 19. században büntetójogi példák.kal; 2001: 1848-1849 és a XIX. századi modernizáaionk; 2004: Traditionelle Wertordnung in Europa und die Wertordnung der Aufklärung in der Konstituirung der Staaten; 2004: Hatalmi elitek a XIX. sqáąadi modernizációban; 2004: Deák und die Modenisierungsprozesse des 19. Jabrbunderts; 2004: Deák és a 19. sqáaadi modernizációs folyamatok; 2004: A polgári korszak igazságügy-miniszterei és az európai jogi kultúra; 2004: Kossuth Lajos korának vezetö rétegei: A kormányzati elit egyes kérdései a tizenkilencedik századi modernizáaió során Közép-és Kelet-Európában; 2004: A magyar jogalkotás a XIX. sqáąadban és tanulságai a XXI. sұáaqadra nézve; 2004: Gesetzgebung und Systemveränderungen; 2004: Hatalmi elitek a XIX. sqáaadi modernizációban; 2004: Traditionelle Wertordnung in Europa und die Wertordnung der Aufklärung in der Konstituirung der Staaten; 2005 Tradicionális jogi értékek - modern alkotmányos értékeek; 2005: Deák-vázlat egy jogászi habitushoz; 2006: Valabányszor e nemzet alkotmányos életfájára az irtó bárd nehezedett), sôt utolsó éveiben a téma német nyelvü összegzésére is vállalkozott (2017: Charakterisieren der modernen ungarischen Rechtsentwicklung im 19. Jahrbundert).

A Kajtár István tiszteletére készített tanulmánnyal, amely a fenti modernizáció-történettel kapcsolatos kutatásokhoz csatlakozik, egyben köszönetemet is szeretném kifejezni mindazért, amire megtanított. ${ }^{2}$

\section{Az egyházak és az állam közötti viszony modernizálásának modelljei}

\subsection{A tradíció és a modernizálás dilemmája Anglia egyházi viszonyaiban}

„Fejedelmek születnek, akik a hatalomban nagyobbak, de természetükben a többi halandóval egyenlöek, és a kormányzás joga vagy az abban való jártasság nem vonja maga után más dolgok, legkevésbé az igaz vallás biztos ismeretét. ’

\footnotetext{
2 A téma bővebb, a házassági jog szekularizációjára is kiterjedő kifejtését lásd HERGER, Polgári állam és egyházi autonómia 7-62. valamint HERGER, A nővételtől az állami anyakönyvvezetőig, passim.

${ }^{3}$ LOCKE, Levél a vallási türelemről 26.
} 
Az állam és az egyház kapcsolata Angliában mindig sajátos volt. A katolikus nemzeti egyház korában az előkelők - ellentétben a német fejedelmekkel - a Rómával folytatott politikai csaták során uralkodójukat támogatták, és nemzeti érzelmeitől indíttatva számos esetben maga a klérus is vállalta a pápai hatalommal való szembeszegülést. 1534-ben az anglikán nemzeti egyház (national church) kifejezetten az angol nép reformált egyházaként jött létre. Vallási homogenitásról azonban többé szó sem lehetett; sőt a felekezeti (anglikán-katolikus) illetve felekezeten belüli (anglikánpuritán) ellentétek jelentős mértékben hozzájárultak ahhoz, hogy a 17. század közepén Anglia a parlamentáris monarchia kialakulásához vezető útra lépjen. Ezen az úton járva vált egyre hangosabbá a kérdés, hogy a jogegyenlőség elve hogyan egyeztethető össze az alattvalóból állampolgárrá váló angolok vallási szempontból diszkriminált jogi helyzetével. Bár az egyházak jogállását tekintve jelentős reformokra került sor a klasszikus liberális korban (1832-1914) is, az anglikán Church of England 1689 óta a többi felekezettel szemben immár államegyházként (established church) nyert értelmezést, és ezt a pozíciót megórizte napjainkig: privilegizált jogállását a modern alkotmányos monarchia keretei között olyan módon tartották fenn, hogy mindeközben a nem anglikánok igénye is érvényesülhessen az egyéni vallásszabadságra és a közösségi vallásgyakorlás szabadságára. ${ }^{4}$

Az államhatalom és az egyház összekapcsolódásának kezdetét az angol jogtörténetben 597től, a Rómából kiküldött térítők kenti partraszállásától lehet számítani. I. Gergely (590-604) céltudatos tevékenysége azonban nem csak az 5. században dél-keletről beözönlő angol, szász és jüt törzsek pogány kultusza ellen irányult, hanem az óbrit és ír-skót irányzat (kelta kereszténység) ellen is. Miután Northumbria királya, Oszৃwin 664-ben a Whitbyben megtartott tanácskozáson maga és országa számára is a római vallást választotta, Britannia egésze a katolikus közösség része lett. A normann hódítást (1066) követően a római katolikus egyház Angliában nagyrészt az uralkodói akaratnak alárendelve működött. A westminsteri apátságban megkoronázott Hódító Vilmos - az angol-szász korszak széttöredezettsége után - erôs, központosított uralmat épített ki. A hódítás jogán minden földtulajdon az uralkodót illetett meg, amelyből 1/4 részt egyházának adományozott. Legfóbb konfliktusforrásnak az állam és az egyház viszonyában a királyt illető kegyúri jog ${ }^{5}$ gyakorlása bizonyult. Vazallus egyháza vonatkozásában Vilmos ragaszkodott kegyúri jogához a püspökök kinevezése során. VII. Gergely pápa (1073-1085) tiltakozása ellenére a király gyakorolta a gyưrűvel és bottal való invesztitúrát is. A főpapok hủbéresküt tettek az uralkodónak és engedélye nélkül nem hagyhatták el Angliát. ${ }^{6}$ A politikai támogatásért cserébe az egyházi adót eljuttatták Rómába, de Vilmos nem tett a pápának húbéresküt, pápai bullát tudta nélkül nem lehetett kihirdetni, és pápai legátus engedélye nélkül nem léphetett be az országba. A normann uralkodók egyházpolitikája - kisebb eltérésekkel - ezt a mintát követte.

\footnotetext{
4 Ehhez hasonlóan államegyház Skóciában a kálvini-presbiteriánus egyház, de a Church of Wales, azaz Wales és Monmouthshire anglikán egyháza önként mondott le 1920. március 31-én az államegyházi pozíciójáról (Welsh Church Acts, 1914, 1919), mint ahogy ezt már 1871-ben megtette a Church of Irland is.

${ }^{5}$ BETHELL, English black moncks 673-698.

${ }^{6}$ FRIEDBERG, Grenzen zwischen Staat und Kirche 730.

${ }^{7}$ FrIEDBERG, Grenzen zwischen Staat und Kirche 732.
} 
Míg a vidék lakosságát sokkal inkább a „testvérek” igehirdetése kötötte le, ${ }^{8}$ az 1207 utáni évek egyházpolitikai küzdelmei jelentősen hozzájárultak ahhoz, hogy Steven Langton canterbury érsek vezetésével a renddé szerveződő klérus is fellépjen az uralkodói koncentrált hatalomgyakorlással szemben. A Magna Carta Libertatum kikényszerítését (1215. június 15.) követően, a 13. század során kiépülő duális rendi államban a főpapi kar - a Lordok Házában helyet foglalva - fontos politikai-közjogi tényezővé vált.

A pápaság és az angol állam illetve a nemzeti egyház viszonya a 14. század második felében éleződött ki. Anglia vallási viszonyait ez idő tájt leginkább a pápai igazságszolgáltatási és pénzügyi politikával szembeni ellenérzés jellemezte. A péterfillérek és a betöltetlen püspökségek javadalmainak Rómába utalása a nemzeti vagyon jelentős részét elszívta. Az 1353. évi Statute of Provisors szerint „Anglia szent egyházát” a király és a nemesség látta el beneficiumokkat és ezek az ország jogának védelme alatt állnak. III. Edvárd (1327-1377) 1376-ban a Jó Parlament összehívásával ennek a felfogásnak kívánt érvényt szerezni, a végső döntés előtt azonban kikérte John Wyclif oxfordi egyetemi tanár véleményét. Wyclif igennel válaszolt arra a kérdésre, hogy a parlament jogosan tartja-e vissza az ország kincseit, mire IX. Gergely (1227-1241) öt átokbullát adott ki a teológus ellen, a akit, bár élet során egyházi hatóság egyszer sem marasztalta, a konstanci zsinat (1414) arra ítélt, hogy „260 tévelygést” tartalmazó könyveit és exhumált csontjait megégessék. 1393ban a Statute of Winchester az 1353. évi rendelkezést megerősítve szigorú büntetést írt elő a királyi bíróságok hatáskörébe tartozó kérelmeknek az országból történő kivitelére. Kétségek merültek fel a pápa státuszát illetôen is: Róma püspökeként nem tekinthették olyan személynek, akinek angol bíróságok writet küldhetnek, vagy aki angol alattvalót kiközösíthet. Anglia már ekkor, a 14-15. század fordulóján függetlenedhetett volna Rómától, IV. Henrik (1399-1413) azonban a pápa elkötelezett híveként 1401-ben parancsot adott a Wyclif-követő lollardok megégetésére. A királyi hatalom csak addig tartott igényt a reformgondolatokat kifejtô teológiai irányzat támogatására, amíg Anglia politikai érdeke pápai hatalom befolyásával szemben ezt megkívánta. A konfliktust alapvetően jogi, nem pedig teológiai szempontból oldották meg.

Az angol nemzeti egyház létrejöttének közvetlen kiváltó oka az volt, hogy a mézeshetek után tizenöt évesen megözvegyült Aragóniai Katalin és az elhunyt Artúr herceg után angol trónra kerülő fivér, VIII. Henrik 1510-ben kötött házasságát az utóbbi - új házasság és fiú örökös reményében - a pápai szentszékkel érvényteleníttetni kívánta. Ennek sikertelensége azt eredményezte, hogy az angol uralkodó számára kiútként csak a római katolikus egyháztól való elszakadás, a reformáció speciális angol útja maradt. VIII. Henrik képzett teológus volt, aki a Martin Luther ellen írt szenvedélyes hangvételű munkájáért (Assertio septem sacramentorum adversus Martinum Lutherum, 1521), a Fidei Defensor címet is megkapta a pápától. A reformáció szellemi tartalmából igazán csak William Tyndale 1528-ban Antwerpenben megjelent írása a keresztény ember engedelmességéröl (The Obedience of a Christen man, and how Christen rulers ought to govern, wherein also if

\footnotetext{
${ }^{8}$ A 13. században az egyház keretein belül megvalósuló új szellemi mozgalom volt a barátok testvéri szövetsége. A brotherhood vándor prédikátorait nem az egyház csillogása, hanem a lelkek megmentése foglalkoztatta, és a keresztény igazságokat az egyszerủ emberek körében hirdették. Lásd MCDONELL, The Beguines and Beghards in Medieval Culture, passim.

9 Wyclif következetesen vallotta, hogy az elvilágiasodott hierarchia jobban tenné, ha birtokait világi felsőségre ruházva visszatérne az evangéliumi szegénységhez. Nézete szerint a világi uralom (hatalom) közvetlenül Istentől származik és ezért közvetlenül Istennek felelős a hatalomgyakorló minden egyházi közvetítés nélkül. GILCHRIST, The Social Doctrine of John Wyclif 157-165.
} 
thou mark diligently thou shalt find eeyes to percieve the crafty convience of all ingglers) ragadta meg, azonban ez sem hitújító tanai miatt, hanem azért, mert Tyndale az államhatalomnak való engedelmesség fontosságát taglalta. A király 1529-ben a parlamentet abból a célból hívta össze, hogy a Rómától való elszakadást kellő módon előkészítsék. Canterbury érseke érvénytelenítette az uralkodó házasságát, majd 1534-ben a parlament (Act of Supremacy) rendelkezett arról, hogy Jézus Krisżtus után az egyház feje (supreme head) a király, és hazaárulást követ el az, aki Henrik jogát kétségbe vonja. A Titkos Tanács által szerkesztett Oath of Supremacy (1535) elnevezésű szöveg elmondásával esküt kellett tenniük az állami tisztviselőknek és a neves magánszemélyeknek is. Mivel az eskü elmulasztása halálbüntetést vont maga után, Aragóniai Katalin halálát követően leánya, Mária is letette azt. Az 1532 és 1536 közötti évek törvényhozása következtében Anglia politikai értelemben protestáns állam lett annak ellenére, hogy a katolicizmus egy ideig még népszerủ maradt. 1536 és 1539 között VIII. Henrik 560 rendházat és kegyhelyet záratott be. Míg a szerzetesek vándorló koldusként folytathatták életüket és a rendházak birtokait az uralkodó a környék nemeseinek adományozta, tovább folytatódott a protestantizmus kontinentális áramlataihoz tartozó személyek üldözése is. Az elszakadás politikai, nem pedig vallási mivoltának igazolását jelentette 1540-ben az Act of the Six Articles, amelyben a parlament a római katolikus teológia újra alkalmazásáról határozott.

Az eszmei zűrzavar VIII. Henrik halálát (1547. január 27.) követően érte el a tetőpontját. A kilenc éves Edvárd, Jane Seymour fia mellett múködő régenstanács olyan nemesekből állt, akik tisztában voltak azzal, hogy a volt monostori földbirtokaikat csak akkor tarthatják meg, ha Anglia tartósan és teljes egészében protestánssá válik. Az 1549-ben a törvényhozás útján bevezetett istentiszteleti rendtartás, a Book of Common Prayer megvetette a protestáns liturgia alapjait és az egyház nyelve az angol lett. Véres Mária uralkodásának öt évét (1553-1558) követően I. Erssébet (1558-1603) megpróbált békés választ találni az angol reformáció problémáira. Miközben Skóciában John Knox vezetésével kálvini hatást mutató protestáns államvallás jött létre (1560), Angliában a protestánsok 1559. évi megegyezését követően a királynő mint minden szellemi vagy egyházi ügyben a birodalom legfőbb kormányzója („,Supreme Governor of this Realm ... as well in all Spiritual or Ecclesiastical Things') autoritása alatt álló és az állam szerves részeként múködő nemzeti egyház mereven elzárkózott mind a katolicizmustól, mind a protestantizmus egyéb irányzataitól. 1559. évet éppen ezért az angliai reformáció záró pontjának tekintik.

Az erzsébeti konszolidáció időszakában az angolok jó része a könyv népe (people of the book) lett, ami ekkor kettős értelemmel bírt: a Biblia népe, mint a Szentíráshoz ragaszkodó, a protestantizmusban szellemi megújulást keresők csoportja, és a Book of Common Prayer népe, mint akik politikai érdekből, különösebb hitbeli érdek nélkül csatlakoztak a nemzeti egyházhoz. A konformistáknak az asszociáció második része nem jelentett problémát, ${ }^{10}$ azonban a puritán mozgalom a katolikus tradíciótól való megtisztulásért szállt harcba. A puritanizmus a gyakran hangoztatott anglikán versus puritán ellentétpár tartalmát cáfolva a valóságban nem ellenkezett az angol egyház anglikán karakterével, hanem azon belül a legerőteljesebb és legsikeresebb vallási irányvonal volt, ${ }^{11}$ mely a Rómától való elszakadást követő posztreformációnak aktív és legitim alkotóelemét képezte vallási és politikai színtéren is.

\footnotetext{
${ }^{10}$ MaltBY, Prayer book and people in Elisabethan and early Stuart England 15-18.
}

${ }^{11}$ MALTBY, Prayer book and people in Elisabethan and early Stuart England 9. 
A konszolidáció rövid időszakát követően az 1603-ban trónra kerülő Stuartok katolikus külpolitikai orientációja és a puritánok üldözése csak fokozta a vallási és politikai ellentéteket. A problémákat azonban a parlament önmagában a Magna Carta Libertatumból „öröklött szabadságokera” hivatkozó Petition of Right megfogalmazásával (1628) - természetesen - nem tudta megoldani. Az angol polgári fejlődés a protestáns etikában készen kapta a maga elméletét. ${ }^{12}$ A protestantizmus istenképe szerint az eredendő bűn minden embert terhel, és ez alól senki sem menekülhet saját cselekedetei által, hanem csak Isten ingyen kegyelméből, az egyházszervezet pedig a választott tisztviselők, valamint a szabad és egyenlő jogú egyházközségek megegyezésén alapuló konföderáció-szerủ társulás - ellentétben a római katolikus egyház hierarchikus rendszerével. A politikai színtéren ez a felfogás a jogegyenlőség kívánalmát jelenítette meg. Ahogy a Petition of Right megszövegezői fogalmaztak, a szabadságok minden angol alattvalót megilletvenk, „,árki, bármi is legyen annak rangja vagy állása".

A királyhű, katolikus irányultságú gavallérokkal szemben a polgári parlamentarizmus elvei a rövidre vágott hajviseletű, kerekfejűeknek nevezett puritánok követeléseiben öltöttek testet. Az Oliver Cromwell által vezetett Gyökér és ág nevű parlamenti csoport célja vallási területen a püspöki szervezet eltörlése és a király pápista követőinek az országból való eltávolítása volt. Cromwell személyes vallási, erkölcsi (és politikai) meggyőződésére nagy hatást gyakorolt szüleinek példája, valamint a XIV. Lajos uralkodása alatti erőszakos rekatolizálás elől Angliába menekült, ,francia prófétáknak" nevezett hugenották szellemisége. ${ }^{13}$ A puritán követeléseket segítette elő az is, hogy a polgárháború első két évének gavallér győzelmeit követôen a parlament azzal a feltétellel kapott segítséget a skótoktól, hogy a skót presbiteriánus rendszer szerint átszervezik az anglikán egyházat. Az 1649 és 1653 közötti köztársasági időszakban Cromwell leszámolt az Írországba menekült gavallérokkal, majd - immár lordprotektori hatalmával élve - bezáratta a bordélyházakat és a színházakat. Vallásszabadságot biztosított a római katolikus egyházon kívül minden felekezet számára, és visszahívta Angliába az 1290-ben kiűzött zsidóságot is. ${ }^{14}$

1660-ban Monck tábornok Richard Cromwell elmozdításával restaurálta a monarchiát. II. Stuart Károly a köztársasági időszakban bölcsen presbiteriánus hitre tért, halálos ágyán azonban már katolikus pap oldozta fel. Öt 1685-ben öccse, a katolikus vallású II. Jakab követte a trónon. 1660 utána puritánokat és más protestánsokat disszenterként, azaz az anglikán egyházon kívüli felekezetek tagjaiként üldözték annak ellenére, hogy II. Károly száműzetése idején a hollandiai Bredából kiáltványt intézett az angol néphez, melyben ígéretet tett a vallásszabadság fenntartására. A restauráció évében börtönözték be John Bunyant (1628-1688), a The Pilgrim's Progress címú, világhírnévre szert tett mű íróját is. Bunyan a börtönben eltöltött tizenkét éve után is folytatta az evangélium nyilvános hirdetését. Népszerűségét jelzi, hogy az evangéliumi keresztény irodalom gyöngyszemeként számon tartott könyvét Angliában tíz év alatt százezer példányban adták el, és már a 17. században lefordították több európai nyelvre, így magyarra is.

A vallási intolerancia az 1770-es évek közepére jelentősen háttérbe szorult. 1672. március 15-én II. Károly rendeletében amnesztiát biztosított azoknak a vallási meggyőződésük miatt börtönbüntetéssel sújtott személyeknek, akik politikai bűncselekményt nem követtek el, és

\footnotetext{
12 KÓNYA, Kálvinizmus és társadalomelmélet 333. és 388-392.

13 DAYTON, Theological Rotts of Pentecostalism, passim.

${ }^{14}$ KATZ, Kifelé a gettóból 20. és 44-45.
} 
engedélyt adott nekik magán-összejövetelek tartására. Az angol zsidóság petíciójára (1664. augusztus 22.) reagálva formálisan vallási türelmet hirdetett, amit 1674-ben, majd 1685-ben, a francia nantes-i ediktum visszavonásának évében, újra megerősített. II. Jakab trónra lépésével azonban a Church of England egyeduralmának biztosítása érdekében újra felerősödött a nem anglikán felekezetek üldözése. Sokaknak tűnhetett úgy, hogy a vallási intoleranciával terhelt hagyományokat nyögő vén Európát könnyebb itthagyni, mintsem a kedvezőbb poitikai széljárást várni. Ez idő tájt települt át az Újvilágba George Fox kvéker egyházának (Religious Society of Friends) jelentős részé, köztük a későbbi észak-amerikai angol gyarmat, Pennsylvania megalapítója, a nemesi származású William Penn is.

1688-ban a parlament I. Károly leányát és annak férjét, a protestáns Orániai Vilmost hívta meg a trónra. A két ház együttes követeléseit az angol alattvalók ,jogainak és sqabadságainak oltalmazása és bið̨tositása érdekében” Vilmos, aki „a Mindenható Isten kegyelméböl dicsöségesen közremüködött abban, hogy ez a királyság megszabaduljon a pápaságtól és az önkényuralomtól” illetve uralkodótársa, Mária elismerte, majd törvénybe iktatta. A forradalom vívmányaként számon tartott Bill of Rights (1689) preambulumában elsőként jelölték meg a vallási sérelmeket, II. Jakab azon törekvését, hogy „,...) az általa alkalmazott gonosz tanácsadók, birák és tisztségviselók segitségével (...) elnyomja és megsemmisitse a protestáns vallást és e királyság törvényeit és szabadságait”. Ez az általános, protestáns szóhasználat érvényesült az Act of Settlementben (1701) is, mely szerint a trónképességet kizárja a trón várományosának vagy házastársának katolikus vallása, és trón ilyen esetben a hannoveri ház rangidős protestáns tagjára száll.

Ennek ellenére szó sem volt a protestáns felelekezetek jogegyenlőségéről. 1689-ben, amikor Locke Epistola de tolerantia című műve Amsterdamban megjelent, a Toleration Act rendelkezései értelmében az anglikán nemzeti egyház (national church) helyét a sokkal pragmatikusabb államegyház (established church) megjelölés foglalta el. Míg az anglikanizmus privilégiumokat élvezett, a disszenter egyházak kiválásukért és az 1640-50-es évek politikai radikalizmusáért magas árat fizettek, hiszen jogszabályok sora korlátozta a politikai életben és oktatásban való részvételüket saját államukban. ${ }^{15}$ A lelkiismereti- és vallásszabadság korlátozott mértékben, a jogegyenlőség elvének sérelmével valósult csak meg. Európai viszonylatban, saját korát tekintve mégis haladó jellegú és egyedülálló volt ez az állapot, hiszen a toleranciának a minimális szintje biztosítva volt.

A következő évszázad végére azonban az angolok keresztény és más vallások sorából választhattak, ami Anglia társadalmát sokkal inkább az ekkor ifjúkorát élő Amerikai Egyesült Államokhoz, mint Európa többi részéhez tette hasonlóvá. A restauráció és a Toleration Act kiadása közötti időszakot (1660-1689) általában az „anglikaniæmus tridenti ssinatának” nevezik. 1689 után az államegyház mégsem követelhetett már a királyság minden polgárától hűséget magának. Ez által viszont sokkal tisztábban határozhatta meg önmagát, mint mikor a tisztaság csupán anglikán erény volt. Az 1730-as években a lelkészcsaládból származó, Oxfordban tanult John Wesley vezetésével kibontakozó metodista mozgalom részeként Angliában több mint 360 gyülekezet jött létre, melyek Wesley 1791-ben bekövetkezett halála után kiváltak az anglikán egyházból. ${ }^{16}$ Wesley legfőbb érdemének - társadalomtörténeti szempontból - azt tartják, hogy a társadalmi problémákra nem igazán reagáló anglikán egyházzal ellentétben követőit a Biblia útmutatása alapján szorgalmas,

\footnotetext{
${ }^{15}$ MaltBY, Prayer book and people in Elisabethan and early Stuart England 235.

${ }^{16}$ MCConnel Buckley, Constitutional and Parliamentary History of the Methodist Episcopal Church, passim.
} 
tisztességes életre buzdította, és mély politikai konzervativizmusával az iparvidékeket távol tartotta francia forradalom követésétől, amelyet az ördög munkájának tekintett. ${ }^{17}$ A 18. századi Anglia jellemző színfoltja volt az evangelical revival mozgalom is, ${ }^{18}$ amely nevét a Biblián alapuló, egyszerű hitbeli igazságokhoz való visszatérésről kapta. Az evangéliumi ébredés a puritanizmus újjászületését jelentette, amely ekkor politikai helyett sokkal inkább szociális irányultságú volt.

A 18-19. század fordulójára Anglia vallási viszonyait a kor követelményeinek megfelelően több szempontból átalakították. III. György (1760-1820) felmentette az őket sújtó büntető jogszabályok alól azokat a római katolikus állampolgárokat, akik a király hűségére letették az 1773ban megfogalmazott esküt. ${ }^{19}$ Az 1820 -as évek végének politikai és jogi változásai lehetôvé tették a katolikusok és a nonkonformisták egyenjogúsítását is. Sir Robert Peel miniszterelnök kora politikai stílusának hiteles képviselőjeként tory párttagsága ellenére támogatta ezt a törekvést. Az An Act for the Relief of His Majesty's Roman Catholic Subjects címet viselő törvénycikk (1829) ${ }^{20}$ az egyházi személyek kivételével aktív, illetve eskütétel után passzív választójogot, valamint hivatalviselési jogot biztosított a katolikusoknak. ${ }^{21}$ A tory-anglikán szövetség sikertelenségét és a felekezeti jogegyenlősítés társadalmi támogatottságát igazolta, hogy a toryk 1846 és 1874 között alig öt évre szerezték csak meg a politikai hatalmat. Az I. vatikáni zsinaton 1870-ben elfogadott pápai infallibilitásról szóló dogma azonban már messze túllépte az angol liberális politikai elitt tûréshatárát. William Gladstone, aki ezidőben első ízben volt miniszterelnök, pamfletjében (The $V$ atican Decrees in their Bearing on Civil Allegiance, 1874) nem kevesebbet állitott, minthogy a dogma az angol katolikusokat az angol koronához illetve a pápához való hűség dilemmája elé állítja. A katolikus egyházat a despotizmus magas fokán álló monarchiaként jellemezte, melynek feje „a tömjén fojtogató felhöjébe rejti el a szabadság elleni büneit" (Vaticanism: an Answer to Reproofs and Replies, 1875). ${ }^{22}$

A zsidók politikai egyenjogúsítását ${ }^{23} 1858$-ban a parlament tagjaitól megkövetelt keresztény eskü módosításával valósították meg. Cromwell rendelkezése óta a zsidók szabadon élhettek az ország bármely részében, illetve ha itt születtek, brit alattvalók voltak. Foglalkozási és politikai korlátozások ugyan Angliában is voltak velük szemben, de ezek 1829-ig a nem anglikán keresztényeket is sújtották. 1858. július 26-án, a jogegyenlősítés szimbólumaként, Lionel de Rothschild helyet foglalhatott a Közösségek Házában. Amikor az anglikán vallású, tory Bejamin Disraeli $1837-$ ben parlamenti képviselő, majd 1868-ban első ízben miniszterelnök lett, már nem vallási toleranciáról, hanem - úgy tűnt - sikeres asszimilációról volt szó. A szefárd zsidó örökségét kulturális és etnikai értelemben keresztsége után is nagyra tartó Disraeli a politikai kritikák egy részét azonban az 1870-es évek második felében antiszemita gúnyrajzok formájában kapta meg. ${ }^{24}$

Angliában első ízben 1851-ben tartottak hivatalos népszámlálást. Ennek eredménye szerint a nemzet nem volt olyan mértékben vallásos, ahogy ezt feltételezték. A népesség 60\%-a járt csak rendszeresen templomba. Ezen belül 5,2 millió állampolgár vallotta magát anglikánnak, szemben a

\footnotetext{
17 MCDOWALL, An Illustrated History 124-125.

18 DALLIMORE, Georges Whitefield, passim.

19 Az eskü szövegét teljes terjedelmében közli FrIEDBERG, Grenzen zwischen Staat und Kirche 751-752.

${ }^{20}$ http://www.historyhome.co.uk/peel/ireland/catheman.htm (2020.07. 07.)

${ }^{21}$ Ez utóbbi alól kivételt csak a régens, a lordkancellár és még három más főhivatal képezett, lásd FRIEDBERG, Grenzen zwischen Staat und Kirche 752.

22 MAGNUS, Gladstone 235-236.

${ }^{23}$ KATZ, Kifelé a gettóból 14. és 17.

${ }^{24}$ ENDELman, Disraeli’s Jewishness Reconsidered 109-123.
} 
4,5 millió nonkonformistával és a majdnem félmillió római katolikussal. ${ }^{25}$ Ezek az adatok kétségbe vonták az államegyházi jogállás fenntartása iránti társadalmi igényt. Ennek ellenére Angliában az állam és az államegyház kapcsolatának alapját továbbra is a Rómától való elszakadást követően alkotott jogszabályok képezték, ${ }^{26}$ és az anglikán egyházban csak a következő század derekán erősödött fel az állami semlegesség iránti igény.

\subsection{Az újvilág ígérete}

„Magától értetódönek tartjuk azokat az, igazságokat, hogy minden ember egyenlöként teremtetett, a₹ embert Teremtóje olyan elidegenithetetlen Jogokkeal rubázta fel, amelyekröl le nem mondhat, s ezek közé a jogok közé tartozile a jog az Élethez és a Szabadsághoz, valamint a jog a Boldogságra való törekvésre " 27

A sajátos amerikai modell létrejöttét többek között annak köszönheti, hogy az Óvilágban üldözött vallási kisebbségek tagjai már a gyarmati korban is a szabadság földjeként tekintettek a tengeren túlra. A Mayflower puritánjai még az utazás során „Isten színe elött” megegyeztek (1620. november 11.) a Virginia északi részén alapítandó új kolónia létrehozásának elveirôl. ${ }^{28}$ Kifejezték elhatározásukat, hogy jogi normát és hivatalt csakis a közösség érdekének leginkább megfelelő módon (General Good of the Colony), a jogegyenlőség elvét (just and equal Laws) szem elôtt tartva alkotnak, illetve állítanak fel. ${ }^{29}$ Mindezt természetesen fenséges uralkodójuk, Jakab király hű alattvalóiként, de főként mindkét fél nagy örömére tették. Bár Angliában is elég puritán maradt még ahhoz, hogy hitelveikkel hozzájáruljanak a polgári átalakulás kibontakozásához, a Zarándok Atyák öröksége máig tartó hatást gyakorolt az amerikai alkotmányjog fejlődésére: a protestáns, egyetemes papság elvében gyökerező jogegyenlőségi felfogás és az angol common lawban a Magna Charta Libertatum óta (1215) ősi jogokként hivatkozott szabadságok átkerültek az újvilág politikai-jogi kultúrájába is.

A Mayflower Compact-et aláírókhoz hasonlóan puritánok alapították 1629-ben Massachusetts gyarmatot John Winthrop vezetésével. Az óhazában üldözött vallási kisebbség az új gyarmaton többségbe kerülve sajátos jogok birtokosa lett: a koloniális karta (1629. március 4. ${ }^{30}$ értelmében a

\footnotetext{
25 A népszámlálási adatokat közli és értékeli MCDOWALL, An Illustrated History 141.

${ }^{26}$ Az uralkodó viseli a Supreme Governor of the Church címet. Elsőszámú alattvalója a canterbury érsek, aki rangban megelőzi a miniszterelnököt és a lordkancellárt is. A királyt egyházi szertartás keretében a canterbury érsek koronázza meg. A királyt megilleti az érseki és püspöki székek, valamint az egyéb egyházi hivatalok betöltésének joga, mely utóbbit a First Lord of the Treasury javaslata alapján gyakorol. Számos egyházközségnek a korona a patrónusa, azaz joga van a lelkész jelölésére (ius praesentandi), melyet a belügyminiszter útján gyakorol. A két érsek, valamint a londoni, a winchesteri és a durhami püspök hivatalánál fogva tagja a Lordok Házának. Ezen kívül további 20 hely és szavazat illeti meg a püspököket, amely által hatékony alakítói lehetnek a mindenkori politikai életnek. Az egyházi renddel és a tanokkal kapcsolatos döntések a parlament hatáskörébe tartoznak. Eszerint a zsinatok, valamint a Church Assembly határozataihoz a parlament és a király hozzájárulására van szükség még abban az esetben is, ha az a liturgiai előírások megváltoztatására vonatkozik. Lásd bővebben LEISCHING, Kirche und Staat 20.

27 The unanimous Declaration of the thirteen United States of America. A hivatalos magyar fordítást lásd http://mek.oszk.hu/02200/02256/ (2020. 07. 07.)

${ }^{28}$ A szerződés eredeti példánya elveszett, a két fennmaradt átirat azonban megegyezik. Magyar fordítását lásd BőDY URBÁN, Szöveggyüjtemény 55.

${ }^{29}$ SCHAMBECK - WIDDER - BERGMANN, Dokumente zur Geschichte der Vereinigten Staaten 19-20.

30 The Charter of Massachusetts Bay, lásd BÖDY - URBÁN, Szöveggyüjtemény 56-57.
} 
gyarmati népképviseleti gyúlést kizárólag a puritán közöség tagjai választották meg. Massachusetts Bay puritánjai lelki abszolutizmusukat megőrizve üldözték a másvallásúakat, akik számára egy megoldás maradt: tovább álltak, hogy egy toleránsabb, vagy inkább mondjuk így: nekik tetsző vallást preferáló államot hozzanak létre. Az independens Thomas Hooker tiszteletes és az elégedetlen telepesek egy része 1635-ben alapította meg Connecticut gyarmatot. 1637-ben a connecticuti Hartford, Windsor és Wethersfield városok polgárai alkotmány kidolgozásához kezdtek, mely két évvel később, Fundamental Orders of Connecticut (1639. január 14.) címmel a nyugati világ első írott alkotmányaként fogadtak el. A haladó alapelvek közt különös jelentőséggel tűnt itt fel az „Evangélium szabadságának és tisz̧taságának.” ügye, ${ }^{31}$ az eddigi üldözöttek szabad vallásgyakorlásának elve. Szó sem volt azonban általános vallásszabadságról; Massachusetts példájából semmit sem okulva saját felekezetüket államvallásként intézményesítették. Ez a példa nem volt egyedülálló a demokráciát, jogegyenlőséget és szabadságot még csak most tanuló gyarmatokon, hiszen a tizenhárom közül kilenc gyarmaton államvallást alapítottak. A kongregacionalizmus vált hivatalos vallássá a Connecticut mellett Massachusettsben és New Hampshireben, anglikán lett Virginia, Délés Észak-Carolina, Georgia és New York állam, valamint Maryland, annak ellenére, hogy ez utóbbit 1632-ben a katolikus Cecil Calvert alapította. Az állam és az egyház összefonódásának a legfontosabb külső jegye az említett kilenc gyarmaton - az európai mintához hasonlóan - az volt, hogy a közhivatalokat betöltők számára vallási feltételeket írt elő a gyarmati kormányzat és a kiválasztott egyház az állami adókból támogatást kapott.

New Jerseyben és Rhode Islandben hivatalos vallást nem alapítottak, de a felekezetek egyenlősége maradéktalanul csupán két gyarmaton, Delawareban és Pennsylvaniában valósult meg. ${ }^{32}$ William Penn, a nemesi származású kvéker régi álma egy ideális keresztényi állam létrehozása volt. Penn az állam és az egyház kapcsolatát tekintve e liberális utat választotta, a jogegyenlőség elve azonban nemcsak ezen a területen jelent meg Pennsylvaniába. Itt született meg az első tiltakozás a rabszolgaság ellen 1688. február 18-án. Germantown mennonitái a következőképp érveltek: „És azok, akik embereket lopnak vagy rabolnak, és azok, akiket ö́k adnakés vesznek, nem egyenlöek-e mindannyian? Itt léterile a lelkiismeret szabadsága, mely jogos és ésszerú, legyen ez. ugyanigy a test firikeai szabadsága is”."33

A függetlenségi háború korszakának újjászerkesztett állami alkotmányai és szabadságjogi katalógusai (Bill of Rights) Connecticut kivételével mindenütt védelemben részesítették a szabad vallásgyakorlást, így 1776 után az immár független államokban egyre növekedett az ellenállás az eddigi államvallásokkal szemben. Az újonnan bevándorolt presbiteriánusok, baptisták, metodisták és izraeliták a szabadság reményében jöttek Amerikába, nem pedig azért, hogy most egy másik felekezettel szemben váljanak nem kívánatos kisebbséggé. Virginiában a szabad vallásgyakorlás elvét a George Mason vezetésével 1776. június 12-én megalkotott jognyilatkozat (XVI. cikkely) a következőképp rögzítette: „V allást vagy a Teremtönkkeel szembeni kötelességünket és ennek teljesitését csakis az értelem és a meggyözödés irányithatja, nem pedig kényszer vagy eröszak. Ezért minden embert egyenlö mértékben illeti meg a jog, hogy vallását szabadon gyakorolja, abogyan azt lelkiismerete parancsolja; és mindannyiunk közös

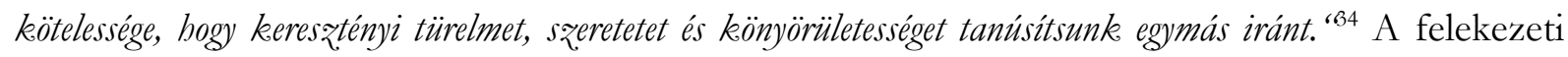

\footnotetext{
${ }^{31}$ Fundamental Orders of Connecticut, lásd SCHAMBECK - WIDDER - BERGMANN, Dokumente zur Geschichte der Vereinigten Staaten 24-29.

32 ALDERMAN - KENNEDY, A nép nevében 367.

33 SCHAMBECK - WidDER - BERGMANN, Dokumente zur Geschichte der Vereinigten Staaten 24-29.

34 Virginia Declaration of Rights, http:/ / avalon.law.yale.edu/18th_century/virginia.asp (2009. 02. 23.)
} 
feszültségek orvoslása érdekében nyolc évvel később a konzervatív szemléletű Patrick Henry egyházpolitikai tárgyú törvényjavaslatot terjesztett a virginiai törvényhozás elé, mely szerint az úgynevezett vallásadót mindenkinek a saját választása szerinti keresztény felekezet részére kellett volna megfizetnie. ${ }^{35}$ Henry javaslata erôs társadalmi vitát váltott ki, hiszen az amerikai politikai közgondolkodás a vallást személyes, magánjellegű dolognak tartotta. ${ }^{36}$

Thomas Jefferson és James Madison a tervbe vett vallásadót elfogadhatatlannak tartotta, elsősorban azért, mert egy szabad akaraton alapuló egyházi intézményt kötelező állami intézménnyé alakítottak volna át. Az Emlékezés és tiltakozás a vallási adóztatás ellen címú esszéjében Madison a következőképp érvelt: „Mielótt egy ember a polgári társadalom tagja leš, elsösorban a világegyetem irányitójának alárendeltje. Ezért határozottan állitjuk, hogy egyetlen ember jogát sem lehet a polgári társadalom intézményei által korlátozni. A vallás teljes egészében kivétel a polgári társadalom batásköre alól."37 Miután Henry elvei megbuktak, Madison újra előterjesztette Jefferson törvényjavaslatát a szabad vallásgyakorlásról, melyet az állam törvényhozása 1786. január 16-án fogadott el: megtiltották bármely vallás kötelező támogatásának, azaz a vallásadónak a bevezetését, és lefektette azt az alapelvet, hogy közhivatal betöltéséhez vallási hovatartozást nem lehet előírni. Mivel pedig „a mindenható Isten a szellemet szabadnak teremtette”, e rendelkezések megváltoztatását a törvény az ember veleszületett jogának megsértéseként értékelte. ${ }^{38}$

1787. szeptember 17-én elfogadott föderális alkotmányba csupán egy rövidke megjegyzés került be a vallási kérdésekről a - fent említett előzmények okából - a közhivatalok betöltése, valamint az elnöki eskütétel ${ }^{39}$ kapcsán. A tagállamok közötti kapcsolat konföderációként vagy föderációként történő meghatározása és az alkotmány ratifikálásának kérdése amúgy is súlyos vitákat okozott a Philadelphiában összeült alkotmányozó konvencióban; ${ }^{40}$ a szabadságjogok kérdésével nem akarták tovább terhelni az előkészítést, inkább nyugodtabb időkre halasztották ezek rendezését. Az állam és az egyház viszonyának alkotmányjogi szabályozására tehát - függetlenségi háború idején született tagállami alkotmányok és a virginiai törvénycikk példáját követve - négy évvel később, 1791-ben került csak sor.

Szerzők sora írta már meg a vallásszabadság történetét, hol kissé szentimentálisan, hol a csupasz tényekre összpontosítva, minden esetre gyakran elfelejtve, hogy a természetjog protestáns etikához kötôdő változata mellett az észjogi irányzatnak (a francia felvilágosodás által rabul ejtett természetjognak $)^{41}$ is jelentôs szerepe volt az amerikai politikai gondolkodásban és az alkotmányos rendszer kialakításában. Mindegyikük szeme megakadt azonban azon a történelmi pillanaton, amikor a csecsemőkorból éppen kinövő nemzet Alkotmányozó Atyái azután, hogy az új föderális állam szervei megkezdték múködésüket, a kedvező időpontot kivárva az állami és az egyházi szféra következetes elválasztása mellett döntöttek.

\footnotetext{
${ }^{35}$ FreEDOM, Church and State in America 140-146.

36 PfEFfer, The Liberties of an American 33.

37 ALDERMAN - KENNEDY, A nép nevében 368.

38 The Virginia Statute of Religious Liberty, lásd SCHAMBECK - WIDDER - BERGMANN, Dokumente zur Geschichte der Vereinigten Staaten 145-148.

${ }^{39}$ NAGYNÉ SZEGVÁRI, Az elnök a kormányzatban 22-40.

${ }^{40}$ KÉPES, Az amerikai állammodell 38-44. és NAGYNÉ SZEGVÁRI, Az USA alkotmányos rendszerének kialalkulása 4161.

${ }^{41}$ Lásd bővebben: HERGER, Szakrális kontra szekuláris értékek a polgári modernizáció korában 33-44.
} 
A konzervatív, eddig államegyházi pozícióban lévő felekezetek belátták, egyikük sem rendelkezik elegendő társadalmi támogatottsággal ahhoz, hogy államegyháziságát az egész nemzetre kiterjessze, bár Jefferson szerint félő volt, hogy a számtalan, kálvini tradíción álló felekezetek együtt ezt megtehetik. A vélemények sokfélesége ellenére a felekezetek abban egyetértettek, hogy mindegyik szabadságot igényelt saját magának. Ennek megszerzéséhez az egyedüli útnak az látszott, ha e jogot mindenki másnak is egyenlő módon biztosítják. Megszűnt tehát a különbség a korábbi államegyházak és más vallási egyesülések, illetve a konzervatív és a radikális csoportok között, bár az utóbbiak elvből, az előzőek pedig csupán szükségszerűségből álltak az általános vallásszabadság mellett. Az eredmény a vallási gondolkodás és az intézményesítés egy komplex képe lett, amely tipikusan amerikai volt, és amely legjobban a denominacionalizmus ${ }^{42}$ (felekezetiesség) kifejezéssel jellemezhető. Az egyházak ezzel mintegy egyesületi jellegű szabályozást nyertek, melynek következtében az eddigiek mellé új, ekkor alapított felekezetek léptek, tovább tarkítva az amúgy is színes képet.

Az Alkotmány 1791. évi első tíz kiegészítő cikkelye, melyeket együttesen az angolszász tradíció szerint a Bill of Rights nevet viseli, a klasszikus szabadságjogok közül első helyen a vallásszabadságot emelte ki: „A kongresszus nem alkot törvényt vallás alapitása vagy a vallás szabad gyakorlásának eltiltása tárgyában”. ${ }^{43}$ E két alapelv gyakorlati érvényesítése, a különböző egyházak kiváltságainak megszüntetése az alkotmány kihirdetését követő mintegy negyven évben nagyobb nehézségek nélkül történt meg - Virginia kivételével - minden tagállamban, úgy, hogy az egyházak vagyoni jogainak megsértésére vagy megszüntetésére sor került volna. Hozzá kell tenni azt is, hogy messze nem a keresztény világnézet vagy a valláshoz való ragaszkodás megtámadásáról volt szó, és a lakosság valóban nem is ekként értékelte a rendelkezéseket. Bár a föderális alkotmány keretei között a tagállamok joga eltérően szabályozhatta/hatja a vallási viszonyokat, néhány keleti parti tagállam partikuláris jogfejlődésétől eltekintve részletekben is egységes elvek mentén alakult az állam és az egyházak közötti kapcsolat.

Mivel a Bill of Rights vallási vonatkozású félmondata a kongresszus irányában jelentett kötelezettséget, 1868-ban az alkotmány módosításával határoztak arról, hogy egyetlen állam sem hozhat vagy alkalmazhat olyan törvényt, mely korlátozza az Egyesült Államok polgárait megillető jogokat (XIV. cikkely 1. §). Így a tagállamok és az unió közötti kapcsolat egyes vonatkozásainak rendezése kapcsán az elsô cikkely ez utóbbi védelme alá került.

1878-ban a Szövetségi Legfelsőbb Bíróság (Supreme Court) ${ }^{44}$ a Reynolds contra U.S. 98 U.S. 145 ügyben hozott ítéletével először értelmezte az alkotmányi rendelkezéseket az 1791 óta eltelt 180 év során. Az Utahban élő mormon vallású Reynolds felekezeti jogának megfelelően két feleséget vett, ami az Unió joga szerint búncselekménynek minősült. Reynolds érvelése szerint a poligámia számára vallási elv, tehát a kongresszus őt szabad vallásgyakorlásában sértette meg. A bíróság ítélete szerint azonban az első módosítás semmiképp sem foszthatja meg a kongresszust attól, hogy megbüntesse a szociális szokások vagy a társadalmi rend felforgatóit, mint ahogy fel kellene lépnie abban az esetben is, ha bizonyos vallási cselekményekhez szükséges emberáldozat végrehajtására

\footnotetext{
42 MEAD, Das Christentum in Nordamerika 55-57.

43 http://www.verfassungen.net/us/verf87-i.htm (2020.07. 07.)

${ }^{44}$ GALLAI, A Legfelsőbb Bíróság szerepe az Egyesült Államokban 63-82.; MCCLOSKEY: Az amerikai legfelsőbb Bíróság 35-41.; MuRPHY, Congress and The Court 7-69.
} 
kerülne sor. ${ }^{45}$ Mindezekből kitúnik, hogy a szabadságjogok - természetesen - nem abszolút jellegúek, azaz a vallásszabadság nevében elkövetett olyan cselekmények, melyeket a büntetőjog büntetni rendel, nem megengedettek. Hogy a határvonalak hol húzódnak, arról a Szövetségi Legfelsőbb Bíróság dönt, ha a föderális alkotmányban foglalt jogra történő hivatkozás miatt egy ügy tagállami bíróságtól szövetségi szintre kerül át.

A ,kongresszus nem alkot törvényt vallás alapitása (...) tárgyában” kitételt (ún. alapítási klauzula) 1947-ben az Everson contra Board of Education 330 U.S. 1 ügy kapcsán értelmezték. ${ }^{46}$ 1941-ben New Jersey oktatásügyi minisztériuma utasította az iskolákat, hogy az állam minden diákja számára biztosítsák az iskolabuszok használatát, függetlenül attól, hogy egyházi, magán vagy állami iskolába járnak-e, és a közlekedés költségeit a szülőknek térítsék meg. Egy adófizető polgár, Arch R. Everson a bíróság előtt megkérdőjelezte a minisztérium jogát arra, hogy ilyen rendelkezést hozzon, mert ezzel szerinte az állam egyházaknak nyújt támogatást. Miután a keresetnek helyt adó elsőfokú ítéletet a tagállami felsőbíróság (New Jersey Court of Errors and Appeals) megváltoztatta, Everson a Szövetségi Legfelsőbb Bírósághoz fordult. Ez döntésében az államot és az egyházat elválasztó alkotmányos szabályozást olyan „magas és átjárhatatlan“ falhoz hasonlította, ami a kongresszust és az államokat egyaránt kötelezi. Rögzítette, hogy az alapítás ténye abban az esetben áll fenn, ha a jogszabály valamely vallást illetve minden vallást segíti, vagy egyiket a másikkal szemben előnyben részesíti. Amennyiben az adott felekezeti iskola tevékenysége az állami követelményeknek megfelel, az iskolaválasztás csakis a szülők döntésétôl függ, a new jersey-i program keretében pedig nem az iskolákat, hanem - felekezeti hovatartozástól függetlenül - a családokat illetve azok gyermekvállalását támogatták. Ezek alapján a tagállami jogi normát a Szövetségi Legfelsőbb Bíróság nem találta alkotmányellenesnek.

1984-ben Sandra Day O'Connor bírónő javaslatára az elveket két szempontra leszúkítve foglalták össze: az elfogadásra kerülő törvény nem jelenthet intézményes beavatkozást az egyházi szférába, és a kormányzatot nem vezetheti olyan szándék, hogy egyetértését vagy rosszallását fejezze ki. Ennek alapján szüntették meg az egyházi iskolák szövetségi pénzből történő támogatását, a kötelező iskolai istentiszteleteket és a vallási jelképek köztulajdonban lévő területen való felállítását is.

A Bill of Rights vallásszabadságot biztosító rendelkezésének második, ún. szabad vallásgyakorlás klauzulája a kongresszus számára állít fel korlátot az által, hogy a vallásos meggyőződést nem korlátozhatja, illetve nem nehezítheti meg annak gyakorlását. Az eljárás során tehát a bíróság azt vizsgálja, hogy komoly-e az a vallásos meggyőződés, amelynek állítólagos sérelme miatt az állampolgár keresetet nyújtott be, és ha valóban komoly, akkor egyensúlyban áll-e a korlátozás az államnak ahhoz füződő érdekével. Ez utóbbi ugyanis csak akkor érvényesülhet, ha bizonyítást nyer tényleges szükségszerűsége. Ezek az elvek a Sherbert contra Verner, 374 U.S. $398^{47}$ ügy kapcsán kristályosodtak ki 1963-ban, amikor a Szövetségi Legfelsőbb Bíróság megállapította, hogy a munkanélküli segélyt nem lehet megtagadni attól a hetedik napi adventistától, akit azért bocsátottak el, mert szombaton nem dolgozott.

\footnotetext{
45 TresolinI, American Constitutional Law 442-443.

46 Tresolini, American Constitutional Law 458-465.

47 ALDERMAN - KENNEDY, A nép nevében 65. és 369.
} 
A Cantwel contra Connecticut 310 U.S. $296^{48}$ ügyben 1940-ben született ítélet. Newton Cantwell és két fia, kik a Jehova Tanúi felekezet tagjai voltak, a főként katolikusok által lakott New Havenben indultak adománygyújtő körútra házról házra járva, aminek a következményekéntöt vádpont alapján indítottak ellenük büntetőeljárást, és a bíróság ezek közül többen bűnösnek mondta ki ôket. Connecticut állam joga szerint ugyanis a pénzgyüjtéshez előzetes engedélyt kell kérni a Public Welfare Council (Közjóléti Tanács) titkárságától, amit az apa és két fia elmulasztott, fonográflemezeik hangos lejátszásával pedig megsértették a közrendet és a katolikus egyházat. Az itéletben a Szövetségi Legfelsőbb Bíróság az egyes államokkal szembeni elveket rögzítette a vallás szabad gyakorlása kapcsán. 1981-ben a Thomas contra Review Board, Indiana Employment, Security Division, 450 U.S. $707^{49}$ ügyben a Szövetségi Legfelsőbb Bíróság úgy döntött, hogy a munkanélküli-segély jár annak a Jehova Tanúja felekezethez tartozó személynek, aki fegyvergyártó üzemből vallási okok miatt lépett ki. E felekezet egyébként gyakorta került a Szövetségi Legfelsőbb Bíróság, de az ügyek jelentős részében nem a vallásra vonatkozó alkotmányos szabadság, hanem a szólás, a sajtó vagy a gyülekezés szabadságának joga alapján született meg a bírói döntés.

A shawnee Tecumseh, az indián konföderalizmus legnagyobb propagandistája 1810. augusztus 12-i beszédében népe jogait a fehérekkel szemben egy transzcendens lény adományozására alapozta. ${ }^{50}$ A bennszülött amerikaiak szenvedő alanyai voltak a Bill of Rights rendelkezéseit szem elől tévesztő kormányzati ún. keresztény politikának. Az asszimiláció megvalósítása érdekében tradicionális életmódjuknak és ehhez szorosan kapcsolódó kultuszaiknak felszámolását tűzték ki célul, melyrôl az ekkor frissen felállított indián-ügyek feletti felügyeleti feladatokat ellátó Board of Indian Commissioners 1869-ben így nyilatkozott: „A civilizálatlan indiánok státusa mindenkor a kormányzat gyámkodása alatt álljon, hogy további fennmaradásuk érdekében védje öket, és hogy kitartóan nevelje öket a civilizááció princípiumai és a keresz̨énység elvei szerint (...). Ezért a keresz̨ény missziókat támogatni kell, az iskoláikat pedig segiteni. ${ }^{, 51} \mathrm{Az}$ ugyanebben az évben felállított Peace Policy keretében több protestáns csoport tagjai tevékenykedtek a rezervátumokban. A szervezet egyébként alacsony hatásfokú áttérítései nem csak a bennszülött lakosság ellenszenvét növelték, hanem felvetették azt a kérdést is, hogy az államnak van-e autoritása a tradíciók felszámolására és a kereszténység erőszakos terjesztésére.

1887-ben az alaszkai Szövetségi Kerületi Bíróság visszautasította Can-ah-couqua habeas corpus peticióját, melyet azért támasztott, hogy az állam által alapított presbiteriánus missziós iskolába járó nyolc éves fia felügyeletét visszanyerje. Az anyát az iskolai szabályok szerint csupán korlátozott jog illette meg gyermeke látogatására. A bíróság döntését azzal indokolta, hogy a fiú, Can-ca-dab legjobb érdekét ez a rendelkezés szolgálja. ${ }^{52}$ Az erőszakos térítéseket a Bill of Rights két klauzulája alapján csak a századvégen kérdőjelezték meg.

A 20. századba is áthúzódó problémának egyik tipikus esete az Észak-nyugati Indián Temetőket Védő Szövetség pere az Erdészeti Szolgálat (Lyng contra Northwest Indian Cemetery Protective Association, 106 S. Ct. 1319) ellen, melynek célja animista vallásuk szempontjából létfontosságú szent hegy épségének megőrzése és az erdészeti útépítés megakadályozása volt. A keresetet az 1978. évi

\footnotetext{
48 Tresolini, American Constitutional Law 448-451.

49 ALDERMAN - KENNEDY, A nép nevében 369.

${ }^{50}$ SCHAMBECK - WIDDER - BERGMANN, Dokumente zur Geschichte der Vereinigten Staaten 271-272.

${ }^{51}$ Board of Indian Comm'rs Ann. Rep. 10. 1869, közli Dussian, Ghost Dance and Holy Ghost 774.

52 Dussian, Ghost Dance and Holy Ghost 775-776.
} 
az indiánok szabad vallásgyakorlásáról és az 1976. évi nemzeti erdőgazdálkodásról szóló törvények megsértésére alapítva nyújtották be a mintegy ötezer főt számláló yurok törzs képviselői, a Szövetségi Legfelsőbb Bíróság azonban csak az alkotmányos kérdés jutott el a kormány fellebbezését követően. Míg az egyenlő szavazat az alsóbíróság ítéletét erősítette volna meg, az indiánok 5:3 arányban veszítették el az ügyet. A döntést William O’Douglas bíró érvelése szemlélteti legtalálóbban, aki szerint ,a vallás szabad gyakorlásának elvét azért irták elö, hogy megmondja, mit nem tehet a kormány az egyénekekel, és nem azért, hogy azt fejezze ki, mit zsarolhatnak ki az egyének a kormánytól”. "53 A yurok törzs igényét elutasító ítélet már messze nem a 19. századi agresszív indián-politikát, hanem sokkal inkább a vallásszabadság kereteit jelzi. Nem a felekezetek közötti különbözőség a döntés oka, hanem az az objektív körülmény, hogy a kormányzat nem tud megfelelően múködni, ha minden állampolgár vallási elképzeléseinek korlát nélkül helyet köteles biztosítani.

Ahogy a fenti jogesetek jelentôs része is jelzi, a vallásszabadság kérdése egyáltalán nem a múlté az Egyesült Államok történetében. Az 1791-ben lefektetett keretek tág teret biztosítottak ahhoz, hogy az ember ember voltából és méltóságából következő szabadsága személyes hitének megválasztására a közösségi élet során is kiteljesedhessen. ${ }^{54}$ Vallásos célra gyülekezni illetve egyesülni a jogrend keretei között az általános gyülekezési és egyesülési jog alapján adtak lehetőséget a polgároknak és az unió területén lakó más személyeknek is. Mivel az egyházakat a maguk sajátos jogi szervezettségében nem ismerték el, így ha a polgári életben jogalanyként szerepelni kívántak, a jogrendben elfogadott külső formát öltöttek. Az amerikai jogfelfogás az egyes egyházakat (church) megkülönbözteti egyrészt az egyház híveinek összességétől (denomination), másrészt a szervezettől (religious corporation), melyben az egyház a külső jogélet tényezőjévé vált, illetve az egyéb külső jogi szervezeti formáktól. ${ }^{55}$ A corporationt, ha nem jogi jellegét hangsúlyozták, gyaktan religious societynek nevezték. Belső szervezetét, jogrendjét néhány alapvető rendelkezéstôl eltekintve tetszése szerint alakíthatta. Ennek értelmében autonóm szervezetet építhetett ki olyan egyház is, melynek jellege ezt eredetileg kizárta. Religious society létrejöhetett rendszerint incorporation, kivételesen részvénytársaság illetve trust és corporation sole formájában is.

Az incorporation megalapításával a vallási társaság ipso iure jogi személyiséget nyert. Szervezetében fontos szerepet játszottak a trusteenek nevezett elöljárók és a kollegiális szervek is. A trustee vagyoni ügyekben a társaság meghatalmazottja, valamint ő jogosultak arra, hogy a leendő lelkésszel az alkalmazásra vonatkozó szerződést megkösse. A church és a corporation különválasztásából fakadóan ez a szerződés a lelkész egyházjogi helyzetét nem érinti, mint ahogy az egyesületi tagság sem szúnik meg azzal, ha valakit az egyházból kizárnak. Mivel a katolikus egyházjog világiaknak testületi jogokat nem juttat, katolikus egyesületek esetében testületi tagok gyưlése csak kivételesen fordult elő. A trust lényege, hogy aki egyházi célra, akár jogi személyiséggel nem rendelkező vallási egyesület részére is, vagyont köt le, azt egy trustee-re ruházza, és errôl a hatóságnál bejelentést tesz. Az alapító céljának megfelelő felhasználásról a hatóság gondoskodik. A

\footnotetext{
53 ALDERMAN - KENNEDY, A nép nevében 59-69.

54 1990-ben készült felmérések szerint a helyi gyülekezetek száma 250.000 és 300.000 között volt, így legkevesebb 1 gyülekezet jutott a népesség minden 1000 tagjára. Az egyesületi rendszer szerint szabályozott vallásos szervezetek több mint 200 különböző megnevezésű felekezethez tartoznak. Ezek legtöbbjére aktív közéleti szerepvállalás jellemző, melyet a tagok anyagi támogatása tesz lehetővé - az állami hozzájárulás alkotmányi tilalma miatt. Szabadon alapíthatnak és tarthatnak fenn iskolákat, szülőotthonokat, szociális és egyéb intézményeket. Lásd WUTHNOW, Religion and the Voluntary Spirit in the United States 3-21.

55 RÜTTIMANN, Kirche und Staat in Nordamerika 21.
} 
corporation sole esetében azokat a személyeket, akik egy bizonyos egyházi hivatalt viseltek, viselnek és viselni fognak, egyszerre jelenlévőnek képzeli a jog, és jogképes testületté nyilvánítja őket. A testületet a mindenkori hivatalviselő képviseli. ${ }^{56}$ A religious corporationra vonatkozó tagállami jogszabályok megalkotásánál - az állam és az egyház elválasztása elvének megsértése nélkül gyakran tekintettel voltak az adott államban jelentős létszámú felekezetek egyházi jogelveire is. Történhetett ez az általános egyesületi jogtól némileg különböző vallási egyesületi jog keretében, vagy az egyes felekezetekre vonakozó külön egyesületi jog formájában is.

Igen fontos vonása az amerikai társadalomnak, hogy az egyházak és vallási mozgalmak a politikai színtéren is képviseltetik magukat, nem vonulnak vissza templomaik falai közé, hanem érdekeik és jogaik biztosítása céljából vállalják a nyilvánosság előtti megmérettetést. ${ }^{57} \mathrm{~A}$ keresztény világnézet a 19. században, de korlátozott mértékben még azt követően is uralkodó volt, és a közéletben is előkelő helyet foglalt el. Mindez azonban csupán a népszerū és feltűnő arca annak, ami a kevésbé látható dimenziókban, így a gondolkodásmódban és a magánéletben megjelenik.

\subsection{A francia út: a vallástalan állam semlegessége}

„Francia nemzęt, te nem azért vagy, hogy példát kövess, hanem hogy példát mutass. Hazám szabad, mutassa meg tehát, hogy erre méltó is, azáltal, hogy összes gyermekeit ugyanazon jogokban részesitit." 58

Az állam és az egyházak közötti kapcsolat alakításának francia útja, amely - ha nem is követendő, de elgondolkodtató - példaként állt Európa haladó nézeteket képviselő gondolkodói és politikusai előtt, két nagyobb szakaszban valósult meg. Az első szakasz kezdetét az 1789. évi forradalom jelentette, amikor az egyházi privilégiumok felszámolása, a vagyoni szekularizáció, a lelkiismeretiés vallásszabadság deklarálása, az egyház szervezetének átalakítása és az izraeliták emancipációja teljes fordulatot jelentett az ancien régime egyházpolitikájához képest. A gyakori államformaváltozások következtében 1815 után az egyházi viszonyok több tekintetben visszarendeződtek, ami leginkább a royalista erôk legitimitás-keresésével magyarázható. A III. köztársaságban azonban a szabadságjogok előtérbe kerülésével ismét liberális egyházpolitika érvényesült, így az állam és az egyház elválasztásának következetes megvalósításával a 20. század legelején pont kerülhetett a mondat végére.

E két szakasz történelmi előzményeit tekintve nem hagyható figyelmen kívül, hogy a francia abszolút monarchia ${ }^{59}$ tisztán világi karakterű volt, szemben a középkori hierarchikus-feudális rendszerrel. A pápai világuralom eszméjének megtörésével olyan új államegyházi rend bontakozott ki, amely a monarchikus abszolutizmus erôs támaszát képezte. A főpapi székek betöltésére vonatkozó erőteljes uralkodói jogosítvány - az I. Ferenc és X. Leó által 1516-ban kötött konkordátum értelmében - garantálta a francia klérus királyhűségét. A katolicizmus nem csak államvallás, hanem kizárólagos vallás is volt 1598-ig, amikor navarrai Henrik Nantes-i Ediktuma

\footnotetext{
56 WeRTHEIM, Wörterbuch des englischen Rechts 164ff. és THOMPSON, Kirche und Staat 104ff.

57 WALD, Religion and Politics in the United States 266-291.

58 Rabaud-Saint Etienne protestáns lelkésznek az Alkotmányozó Nemzetgyúlésben a vallásszabadság törvényi rögzítése kapcsán elhangzott beszédét idézi DE PRESSENSÉ: L’Église et la Révolution française 56.

${ }^{59}$ HinZE, Wesen und Wandlung des modernen Staats 470-496.
} 
elismerte a hugenották protestáns vallását és biztosította az alattvalók vallásszabadságát. ${ }^{60} \mathrm{~A} 17$. században Richelieu és Mąarin kormányzó első miniszterek ezeket a kedvezményeket fokozatosan felszámolták, majd 1685-ben XIV. Lajos Fontainebleau-i Ediktumával visszavonta IV. Henrik rendelkezését. A kilenc évtizednyi vallási türelem után ismét vészterhes idők következtek, mikor a francia protestánsok egy része katolizált, mások külföldre menekültek, sőt volt aki (les camisards) a fegyveres ellenállást választotta. A lelkiismereti szabadság megmaradt ugyan, de a vallásgyakorlás szabadsága erôsen korlátozott volt. ${ }^{.1}$

A gallikanizmus, az önálló nemzeti egyház és az abszolút uralom világi jellegének követelménye többek között a francia klérus 1682. évi nyilatkozatában öltött testet. Míg a középkorban Aquinói Szent Tamás Isten országáról (De Civitate Deı) szóló tanításában az egyház azon jogát hirdette, hogy a világi uralom felett erkölcsi értékítéletet alkothat, és ha annak céljai az egyházi elvárásoknak nem felelnek meg, a királyt uralkodói méltóságától megfoszthatja, addig a nyilatkozat szerint a fejedelem világi dolgokban nem áll az egyház tekintélye alatt. A XIV. Lajos által Párizsba összehívott nemzeti zsinat Jacques Bénigne Bossuet püspök vezetésével 4 cikkelyben fogalmazta meg és hirdette ki az ecclesia gallicana szabadságait, melyek röviden összefoglalva a következők: 1. Az egyház csak szellemi dolgokban rendelkezik hatalommal és a fejedelmek világi ügyekben függetlenek ettől; 2. szellemi dolgokban is korlátozza a pápai hatalmat az egyetemes zsinat tekintélye; 3. a francia király törvényei és a szokások az eddigi gyakorlatnak megfelelően továbbra is érvényben maradnak és 4. hitbeli kérdésekben a pápai döntéseket az egyetemes egyháznak meg kell erôsítenie. ${ }^{62}$ Taine szavaival élve „a király parancsoló hangja és a papság alázatos viselkedése mit sem változtat a dolgon, közöttük megtörtént az alku; az egyik ád, hogy a másik is adjon (...)”."33 Míg tehát a dinasztia és a francia klérus a kölcsönös érdekek jegyében együttműködött, a 18. századi közvélemény felvilágosult formálói a dogmatikai kritikán túl a az egyházat társadalmi szempontból is megítélték: hatalmas és költséges intézményt láttak benne. Számos írás foglalkozott az egyházi vagyon és a tizedfizetés eredetével, illetve a szerzetesi élet haszontalan voltával és a papság erkölcsi félresiklásaival, sőt a fôpapi kar jelentős részének hitetlenségével. „Alig hisz̨em, írja a pfalz̨i grófnő 1772-ben, hogy Párizsban akár az egyháziak, akár a világiak közö̈tt lehetne még száz embert találni, kinek igaz. bite volna, söt aki binne a mi Urunk és Megváltónkban. ${ }^{\text {"64 }}$

Az elsô, ún. forradalmi szakasz reformjaihoz a vallásszabadság, az egyházi előjogok és a tized, a vagyoni szekularizáció, az egyházalkotmány, az egyházi hivatalnokoktól megkövetelt hűségeskü valamint a zsidók emancipációjának kérdése tartozott.

A papi rend szabadelvűsége ${ }^{65}$ a vallásszabadság kérdésében - ellentétben az általuk is követelt politikai jogokkal - mereven elutasító volt, azaz nem terjedt ki a lelkiismereti szabadság elismeréséig sem. E tekintetben különösen nagy volt az eltérés a harmadik rend programjától. Az 1789. augusztus 26-án elfogadott, egy későbbi alkotmány bevezetőjének szánt Emberi és Polgári Jogi Nyilatkozat X. cikkelye deklarálta, hogy senkit sem szabad meggyőződése, illetve vallási

\footnotetext{
${ }^{60}$ Owen, A reformáció 158-160. és MCGRATH, Kálvin 189-209.

${ }^{61}$ Magony, A francia egyház 7.

62 MiRBT: Quellen zur Geschichte des Papsttums 389-390.

${ }^{63}$ TAINE, A jelenkori Franciaország alakulása I. 102.

${ }^{64}$ Idézi TAINE, A jelenkori Franciaország alakulása I. 451.

${ }^{65}$ DE PRESSENSÉ, L'Église et la Révolution française 32.
} 
meggyőződése miatt zaklatni, ,feltéve, hogy (...) e nézetek megnyilvánulása a törvényes rendet nem sérti” ${ }^{66} \mathrm{~A}$ vallás szabad gyakorlásának ügye a felvilágosult irodalmon felnövekvő új nemzedék programjában első helyen állt, említésre méltó azonban, hogy a hivatkozott elődök, Montesquieu ${ }^{67}$ és Rousseau ${ }^{68}$ korlátok között értelmezték ezt a szabadságot. Az Emberi és Polgári Jogi Nyilatkozat megfogalmazása során - Rousseau nyomán - a közrend védelme és a személyes szabadság elvéből indultak ki. A javaslat a papi rend nagy örömére „a jó társadalmi rend érdekében” fenntartotta az elismert vallást, amely a római katolikus vallás volt, de más felekezeteknek törvényes elismerést nem biztosított. Csupán azt deklarálta, hogy akik a nemzeti vallást nem zavarják, ne háborgattassanak (16-18. cikkely). Mirabeau, az egyházpolitikai vita vezetője hangsúlyozta, hogy ez a javaslat a vallásszabadságnak kétes garanciát nyújt csak: „egy oly batalom létezése, amely türni tud, már magában véve nyilatkozat a hitszabadság ellen, mert hisz az is lehetséges, hogy nem fog türni”. ${ }^{99}$ Indítványozta a javaslat módosítását és a vallásszabadság általános jogának biztosítását minden polgár számára. Az új megfogalmazásból már hiányzott az elismert vallás kifejezés, sốt elég kétértelmű volt ahhoz, hogy senki véleményét ne sértse. A vallásszabadság egyedüli korlátjaként tehát a törvényes rendet adták meg. ${ }^{70}$

Az egyházi előjogok eltörlését és az egyházi tized megszüntetését az alkotmányozó nemzetgyúlés 1789. augusztus 4-én éjjelén (Joglemondó Nyilatkoz̧at) Noailles vicomte javaslatára mondta ki, a decima kérdése azonban már jóval korábban felmerült. Mirabeau gróf azt május 10-i beszédében az uralkodó által bármikor visszavonható évjáradéknak nevezte, tagadta a klérus tulajdonjogát felette, és „az erkölcsiség és nevelésügy hivatalnokainak” (a papságnak) állami fizetését sürgette. ${ }^{71}$ Bár az egyházi tulajdon védelmében másnap Sieyès abbé röpirat (Observations sommaires) útján is kikelt, ${ }^{72}$ ugyanezen a napon, május 11 -én a papság egy része a tizedről minden feltétel nélkül lemondott.

Az egyházi vagyon szekularizációjának igénye 1789 szeptemberében a pénzügyi nehézségek csökkentése céljából vetődött fel a francia sajtóban. A nemzetgyúlésben október 10-én TalleyrandPerigord gróf, autuni püspök indítványozta a szekularizációt. Elképzelése szerint az egyházi javak tulajdonjoga a nemzetet illeti, amely köteles gondoskodni az egyházi szükségletekről, beleértve a lelkészek fizetését is. A katolikus egyház vagyonát a kortársak eltérően becsülték fel; Talleyrandszerényen - a földbirtokok jövedelmét 70 millió, a birtokok értékét pedig 2.000 millió frankra tette, de a legtöbben 130 és 224 millió közötti jövedelmet és 2-4 milliárd frank vagyonértéket említettek. ${ }^{73}$

\footnotetext{
${ }^{66}$ Magyar fordítását lásd http://mek.oszk.hu/00000/00056/html/228.htm (2020. 07. 07.)

${ }^{67}$ Montesquieu fellépett a vallásüldözés ellen, de megvonta az új felekezetektől a hitterjesztés jogát, továbbá a közrend védelme érdekében fontosnak tartotta, hogy a vallásoktól az állam követelje meg azt, hogy az államot illetve egymást ne zavarják. Tehát felfogása szerint a felekezetek az állam tetszésétől függően léteznek és annak felügyelete alatt állnak. Lásd MAGONY, A francia egyház 55.

${ }^{68}$ A deista szemléletű és az egyházak iránt teljesen közömbös Rousseau felemelte szavát úgy a pápa abszolút hatalma ellen, mint a (korlátozott) vallásszabadság érdekében: az istentagadókat nem kell megtűrni az államban, ahol egyébként minden polgár testvér, sőt a szuverénnek joga van arra is, hogy száműzze őket. Lásd LuDASSY, Az ész államáig és tovább, passim.

${ }^{69}$ Idézi DE PRESSENSÉ, L’Église et la Révolution française 50.; magyatul lásd MAGONY, A francia egyház 59.

${ }^{70}$ A törvényes rend mint korlát ellen Mirabeau a Courrier du Provence hasábjain is érvelt. Lásd magyarul MAGONY, A francia egyház 63.

${ }^{71}$ Idézi FRAKNÓI, Az egyházi javak saecularisatiója 3-4.

${ }^{72}$ Idézi MAGONY, A francia egyház 51.

${ }^{73}$ Magony, A francia egyház 5-6.
} 
Az egyházi vagyon eredetéről és jellegéről folytatott vita során a szekularizáció hívei azt hangsúlyozták, hogy az állam az egyház felett áll, korlátlan hatalommal rendelkezik irányába, és adományait, melyeknek az egyház csak kezelője, bármikor visszavonhatja. Mirabeau indítványának megfelelően 1789. november 2-án 568 szavazattal 346 ellenében a nemzetgyúlés kimondta, hogy az egyházi javakat a nemzet rendelkezésére bocsátják, de az gondoskodik az istentisztelet költségeiről, a klérus dotálásáról (lakást és a hozzá tartozó kertet nem számítva minimum 1200 frank értékben) és a szegények segélyezésérôl. ${ }^{74}$

A nemzetgyúlés 1790. március 16-i határozata értelmében 400 millió frank értékű egyházi vagyont adtak át eladásra a párizsi, illetve más városi hatóságoknak. A kincstár fémpénzként funkcionáló, névleges értékkel bíró assignatákat bocsátott ki, amelyeknek az egyházi javak vásárlása során kellett volna az állampénztárba visszajutni és ilyen módon a forgalomból fokozatosan kikerülni. Emellett - a rendkívüli mértékű államadósság és a közszükségek fedezése érdekében Chasset javaslatára tervbe vették a további vagyonelvonást is. Április 14-én a nemzetgyúlés az egyházi javak kezelésének jogát a közigazgatási szervek igazgatóságára bízta és döntött arról is, hogy 1791. január elsejétől a papság kézpénzben kap fizetést. Az egyházi javak szekularizációja a pénzügyi krízist azonban nem tudta orvosolni. 1792. szeptember 22-ig a kincstár 2500 millió, 1793 augusztusáig 4616 millió, 1796 elejéig 45,5 milliárd frank értékben bocsátottak ki assignátákat, amelyek a kereslet csökkenésével forgalomban maradtak és értéküket vesztették. A pénzügyi vezetés 1796 februárjában így arra kényszerült, hogy a forgalomban lévő assignátákat 24 milliárd frank értékre csökkentse, majd újabb hitelpapírokkal (mandats) beváltsa.

1790. május 27-én került a nemzetgyúlés elé a papság polgári alkotmányáról szóló törvényjavaslat. ${ }^{75} \mathrm{Az}$ alapkoncepció szerint az egyházak kormányzattal és szervezettel rendelkező társaságok, amelyek az államban annak alárendelve működnek. Megbízottjaik, a papok fizetett állami hivatalnokok, akik jogállását - a gallikán nemzeti zsinat vagy a pápa helyett - az állam nevében a nemzetgyúlés szabályozza. Az egyházi autonómiát, az öntörvényhozás és az önigazgatás jogát tagadó egyházalkotmány ${ }^{76}$ vitája végletekig fokozta a szenvedélyeket. Hívei a filozófiai érvek mellett a római császárok és a francia királyok egyházszervezési és kegyúri jogait emlegették. Camus szerint a nemzetgyúlésnek akár a vallás megváltoztatására is joga lett volna, nem kevésbé az egyházszervezet meghatározására. Robespierre - Rousseau elveit hangoztatva - kitartott amellett, hogy az állam meghatározhatja a hasznos intézményeket, azaz megszüntetheti a fölöslegeseket, sőt az egyházi hivataloknak feltétlenül függniük kell a nép akaratától, azaz a nép akár meg is házasíthatja papjait, hogy reális kötelékkel kapcsolja őket a nemzethez. ${ }^{77}$ Míg VI. Pius 1790. március 7-én titkos konzisztóriumi beszédében, illetve levelezésében a lelkiismereti szabadság deklarálását és a királyi hatalom méltatlan, erőszakos korlátozását ítélte el, szeptember 22-én már az új egyházalkotmány ellen tiltakozott az uralkodóhoz intézett levelében, majd a püspököket szólította fel ellenállásra.

Az egyházi mozgalmat mégis Voydel javaslata hevítette fel leginkább. A kegyelmi rendszabálynak (mesure d’indulgence) nevezett javaslat minden egyházi hivatalt viselőtől megkövetelte a hűségeskü letételét a nemzetre, a királyra és a papság polgári alkotmányára. A korlátlan

\footnotetext{
${ }^{74}$ Idézi FRAKNÓI, Az egyházi javak saecularisatiója 9-10.

75 Lásd MAgONY, A francia egyház 97-130.

${ }^{76}$ A nemzetgyúlés 1790. június 17-én fogadta el az új egyházalkotmányt, de a királyi szentesítés csak hosszas halogatás után történt meg. Lásd TAINE, A jelenkori Franciaország alakulása II. 287.

${ }^{77}$ Lásd DE PRESSENSÉ, L’Église et la Révolution française 126-131. és 143.
} 
vallásszabadság törvényi rögzítéséért egy évvel korábban síkra szálló Mirabeau most a papság ellenállásának megtörését kívánta, akár a legszigorúbb megtorlás eszközével is, míg Camus a királyi szentesítést sürgetve a pápai befolyás ellen érvelt. A javaslat vitája ismét heves indulatokat váltott ki. $^{78}$ A kedélyek megnyugtatása céljából Mirabeau - hangnemet váltva - 1791. január 26-i emlékiratában a papság polgári alkotmányát és az esküt a vallásszabadság elvével kívánta kibékíteni, ${ }^{79}$ amikor Marat lapjában a népet a papok ellen ingerelte, Desmoulins pedig röpiratában (Révolutions de France et de Brabant) maró gúnnyal támadta a klérust. A király szökési kísérlete (1791. január 21.) után maga a nemzetgyúlés is radikalizálódott. A következmény nem maradhatott el. VI. Pius április 13-i ünnepélyes brévéjében eretneknek nevezte a papság polgári alkotmányát, tiltakozott a püspökválasztások ellen és 40 napot adott a letett eskük visszavonására. Ez a pápai állásfoglalás a francia katolikus papságot és az egyháztagokat két szembenálló táborra osztotta. ${ }^{80}$

Ahogy a gallinkán egyház jogállásának újrarendezése megtörtént, a következetesség jegyében egy olyan területet is érintett a forradalmi jogalkotás, amely régi „adósságok” törlesztését jelentette. Az ancien régime bukásakor mintegy 40 ezer zsidó élt Franciaországban, nagyrészt Elzász és Lotaringia területén. A jogegyenlőség deklarálásának szükségszerű következményeként a nemzetgyúlés keresztény földön elsőként, ámbár hosszas vitát követően, 1791. szeptember 27-én megszavazta a francia zsidók egyenjogúsítását, azonban anélkül tette ezt, hogy a gyakorlati megvalósításhoz a kellő eszközöket biztosította volna. ${ }^{81}$ Léon Haléyy szerint tizenöt évvel később Napóleon a zsidók és nem zsidók közötti különbséget még épp akkorának látta, mint amekkora az az emancipációs törvény előtt volt. ${ }^{82}$ Ha pedig a zsidók önszántukból nem akarnak kilépni örökölt jogállásukból, történjék ez hatalmi kezdeményezésre: az 1806. július 26-ra összehívott izraelita zsinat választ adott mindazokra a kérdésekre, amelyeket a császár képviseletében elé terjesztettek. A vallási törvény alapján elismerte a monogám házasságot és a házasság felbontásának lehetőségét, de kinyilvánította azt is, hogy a vegyesházasságok csak polgári jogi jog szerint érvényesek, valamint az izraeliták, bár foglalkozásukat francia polgárként szabadon választják meg, a Talmud szerint kamatot csak idegenektől szedhetnek. Napóleon szándéka, hogy „,ne legyen többé bocsánat arra, ba valaki más, mint a többi polgár", ${ }^{83}$ ezen határozatok következtében már realizálódhatott. 1807. február 4-ére hívta össze azt a hetven, kétharmad részben rabbi tagokkal rendelkező ünnepélyes izraelita gyúlést, amely azonnak deklarálta, hogy a vallási és politikai elő́rásokat tartalmazó mózesi törvényben a vallásiak abszolút érvényűek, a politikaiak azonban joghatály nélküliek. ${ }^{84}$ A zsidóság tehát nem nemzet többé, hanem vallás, egy a számos lehetőség közül. Az asszimilációnak tág kaput nyitó 1808. március 17-i dekrétum, amely egyébként protestáns mintára állami ellenőrzésnek alárendelt egyházszervezetet (hitközségek - Központi Konzisztórium) is életre hívott, jelentős hatást váltott ki. A francia zsidóság gyorsan bekapcsolódott az ország társadalmi, gazdasági és kulturális életébe. Bár ellenséges megnyilvánulások a későbbiekben is előfordultak, antiszemita politikai mozgalom csak az 1880-as években bukkant fel Franciaországban.

\footnotetext{
${ }^{78} \mathrm{Az}$ 1790. november 27-én elfogadott javaslatot XVI. Lajos végül ez év december 26-án szentesítette, az eskütételt azonban a név szerint előszólított egyháziak közül számosan megtagadták.

${ }^{79}$ Mirabeau emlékiratát közli DE PRESSENSÉ, L’Église et la Révolution française 169-173.

${ }^{80}$ Az eskükényszer következményeit lásd RICHTER, Staats- und Gesellschaftsrecht I. 178-179.

81 RICHTER, Staats- und Gesellschaftsrecht II. 597-601.

${ }^{82}$ HaLÉVY, Résumé de l'histoire des juifs modernes 302.

${ }^{83}$ Idézi RiCHTER, Staats- und Gesellschaftsrecht II. 599.

${ }^{84}$ A határozatt Nagy Szanhedrin nyilatkozata cím alatt illesztették be az 1808. március 17-i dekrétumba.
} 
A forradalmi jogalkotás eredményeit, melyet a konszolidáció időszakában már csak a természetjogi lángolás, a filozófiai szellem szüleményének és átmenetinek bélyegeztek, az I. császárság idején az egyházpolitika területén is több tekintetben a múlthoz való visszafordulás váltotta fel. Napóleon és VII. Pius 1801. évi konkordátuma, melyet 1802. április 18-án hirdettek ki, garantálta az egyház ellátását, de nem fizetés, hanem kárpótlás formájában. Ezzel a Szentszék elállt az elvesztett javak visszakövetelésétől. A konkordátum a katolikus vallást a többség vallásaként az elismert egyház státusába helyezte. Újra felállították a püspökségeket, a püspökök kinevezése azonban állami jogosítvány volt. A konkordátumot a kormány még 1802-ben az ún. 77 articles organiques-kel egészítette ki, melyet a katolikus egyház - azokban szabadságuk megvonását látva sosem ismert el. Az organikus cikkelyek értelmében az érsekek, a püspökök és a lelkészek (eltérő mértékû) járulékban részesültek. Ezek az értékek a későbbiekben jelentősen módosultak, azonban az állami költségvetésből egyházi szükségletre előirányzott összeg az évek során összeadódva jóval meghaladt azt az értéket, amelyet az 1790-ben elvont egyházi vagyon képviselt. Egy évvel a konkordátum megkötését követően az egyházmegyéket és a plébániákat megfosztották önálló jogi személyiségüktől és a katolikus egyház intézkedéseit polgárjogi vonatkozásban semmisnek nyilvánították. A konkordátum és az articles organiques a forradalom idején megvalósított szeparációt felszámolva a katolikus egyházat úgy emelte közjogi személyiséggé, hatósággá, hogy ugyanakkor az államhatalomnak szorosan alá is rendelte. Nyugodtan állíthatjuk, hogy a gallikanizmus eszméinek újjáéledéséről volt szó. ${ }^{85}$

Miután Franciaország a radikális egyházpolitika korszakát, az ész istennőjének trónra ültetését (1793. november 10.), majd napóleoni álbéke idejét túlélte, 1815 és 1870 között némi ingadozással ugyan, de a francia állam és a katolikus egyház kapcsolata jelentôs mértékben visszarendeződött, hiszen egyházi támaszra szüksége volt úgy a restaurált Bourbon uralkodóknak (1815-1830), mint III. Napóleonnak (1852-1870). Az újabb radikális hullám előszelei az után jelentkeztek, hogy III. Napóleon 1859-ben az olasz egységtörekvések élharcosa, Piemont mellé állt. A következő évben Rouland kultuszminiszter memorandumában már az articles organiques visszaállítását kezdeményezte. Nem sokkal később, 1864. december 8-án IX. Pius a Quanta Cura enciklikához csatolt listában elítélte azt a kormányzási formát, melyből az egyház tanításait kizárják, illetve ahol az állam az egyháztól elválasztva múködik. ${ }^{86}$

A szabadelvú egyházpolitika 1879-et követően bontakozott ki újult erôvel. A radikális felfogás szerint - Pillon szavaival élve - „a republikanizálódás akadálya a katolicizmus” volt, azaz „,ha Franciaorsðág meg akarja menteni a köztársaságot, szakitania kell Rómával”, 87 és az államot a laicitás politikai koncepciója szerint kell berendeznie. A III. köztársaság (1871-1946) liberális egyházpolitikája feltételezte úgy az 1789-1804 közötti változásokat, mint azt, hogy az egyházi írók által szabadkőmúves befolyással magyarázott egyházellenes ${ }^{88}$ szemlélet 1815 és 1870 között is

\footnotetext{
${ }^{85}$ BOCHKOR, Francia egyházpolitika 607-609.

86 Az enciklika tételesen felsorolta a tévesnek itélt 80 tant (Syllabus Errorum), ezek között a klerikusok liberális egyesületeit, a polgári társadalmat illetve annak az egyházhoz fűződő viszonyát, a házasság szentségének megkérdőjelezését és a liberalizmust. Az enciklika szövegét lásd http://www.domusecclesiae.de/magisterium/syllabus-errorum.teutonice.html (2020. 07. 07.)

${ }^{87}$ Idézi GOLDSCHMITT, Der Kulturkampf in Frankreich 10.

${ }^{88}$ GOLDSCHMITT, Der Kulturkampf in Frankreich 5.
} 
népszerű maradt annak ellenére, hogy a katolikus nemzeti egyház védelmében számos neves gondolkodó is fellépett. ${ }^{89}$

A radikális párti Jules Ferry oktatásügyi miniszter törvényjavaslatai az egyházi befolyás megszüntetését célozták úgy az elemi, mint a felsőoktatás területén. Az állami egyetemeken ingyenes lett a beiratkozás és csak ezek az intézmények adhattak akadémiai címet. Míg a külföldi sajtó az egyházi egyetemek ,jogfosztását” általában „hivatalos hadüzenetként ${ }^{* 0}$ értékelte a francia katolikus egyház irányába, az 1880. július 9-i szavazás Ferry programjához szabad utat adott. A vallási szempontból semleges oktatási rendszer megteremtése érdekében az elemi iskolák tanárait kötelezték arra, hogy állami bizottság előtt vizsgát tegyenek. Az állami iskolákban eltörölték a tandijat és a vallásoktatást, majd a radikálisok követelésére 1886-ban az állami iskolákból elbocsátották az egyházi rendbe tartozó tanárokat is. Az 1880-as évhez köthetô a nem elismert kongregációkkal szembeni fellépés is. A nemzetgyúlés március 29-én határozott a jezsuita rend feloszlatásáról és kolostoraik felszámolásáról, valamint a nem elismert kongregációkat kötelezték arra, hogy állami elismerést kérjenek. Bár a Times kommentárja szerint „,sak véres forradalmak idején alacsonyul le egy nagy állam ilyen vállalkozásokra", XIII. Leó tiltakozása sem akadályozta meg a rendelkezések következetes végrehajtását. 1884-ben megszüntették a kórházi lelkészi hivatalt és a házszabály eltörölte a parlamenti imát is.

Az 1890-es években több vallási vonatkozású ügy is felkavarta a francia közéletet. 1891-ben mintegy 20 ezer francia zarándok érkezett Rómába, akik a Rerum novarum enciklikát személyesen akarták a pápának megköszönni. Ügyük a nemzetgyúlésben egyházpolitikai vitára adott okot. A francia közvéleményt azonban elsősorban a Dreyfus-per ${ }^{92}$ rázta meg, amelyet a klerikális szakirodalom nemes egyszerűséggel Dreyfus-rumlinak titulált: Alfred Dreyfus kapitány koncepciós pere kapcsán Goldschmitt a „befolyásos zsidók valóságos hadjáratát” emlegette, amelyet szerinte a „radikálisok jól fel is használtak” a reformok szükségességének igazolásához. ${ }^{93}$ Nos, az 1898-as választások után a kormány valóban a megszakadt kultúrharc folytatása mellett foglalt állást. A következő évben elfogadott egyesületi törvény feljogosította a kormányt azon kongregációk felszámolására, amelyek tagjai nagyobbrészt külföldiek voltak, az új vallási kongregációk létrehozását pedig törvényi vagy államtanácsi engedélyhez kötötték.

A szétválás feltételei tehát egyre inkább érlelődtek. 1902-ben a miniszterelnöki széket a teológus végzettségű Louis Emil Combes foglalta el, aki 1885-től szenátor és hosszú időn át a radikálisok vezéregyénisége volt. A kormány 1903-ig elzárkózott a konkordátum felülvizsgálásától, ekkor azonban az üresen maradt püspökségek betöltése ügyében ellentét keletkezett a Combes vezette kormány és XIII. Leó között. Míg a pápa megtagadta a kormány jelöltjeinek kinevezését, Combes ragaszkodott választottjaihoz. Miután 1904. április 4-én a római Szentszék egy titkos tiltakozó jegyzéket küldött a katolikus királyi udvarokba, és azt a monacói fejedelem közzé tette, a francia követ elhagyta a Vatikánt. Április 30-án megszakították a diplomáciai kapcsolatot a pápai udvarral. A szétválasztásról szóló törvényjavaslat nemzetközi érdeklődéssel kísért vitája 1905 márciusában kezdődött meg anélkül, hogy a felekezeteket az előkészítésébe bevonták volna. A

\footnotetext{
${ }^{89}$ BOCHKOR, Francia egyházpolitika 5-10.

${ }^{90}$ Idézi GOLDSCHMITT, Der Kulturkampf in Frankreich 11.

${ }^{91}$ Idézi GolDschmitT, Der Kulturkampf in Frankreich 21.

${ }^{2}$ KAYSER, The Dreyfus Affair, passim.

${ }^{93}$ GOLDSCHMITT, Der Kulturkampf in Frankreich 44.
} 
szeparációs törvényt, amelyet Combes a szabadság, a szociális béke és a morális felszabadulás törvényének nevezett, a képviselők 341 szavazattal 233 ellenében, a szenátus 179 szavazattal 103 ellenében fogadta el. ${ }^{94}$

Az állami semlegesség jegyében ${ }^{95}$ biztosították a lelkiismereti szabadságot és a vallás szabad gyakorlását. Rögzítették, hogy az állam nem ismer el, és nem finanszíroz egy felekezetet sem, tehát a budgetből - a múemlékek fenntartására szolgáló támogatás kivételével - törölték az egyházi kiadásokat. A francia forradalmat túlélő gallikanizmus ezzel eltűnt, az állam ellenőrző hatásköre az egyházak felett megszűnt. A köztársaság biztosította a lelkiismeret és a vallás szabadságát, a vallás szabad gyakorlását, amely csak a közrend érdekében és törvényes módon korlátozható. Az egyházi vagyon azon része, mely az államtól származott, visszaszállt az államra. A jótékonysági vagy nem vallásgyakorlási célt szolgáló javak a hasonló célt szolgáló közhasznú intézmények tulajdonába, míg az egyházi célokat szolgáló épületek állami tulajdonba kerültek. Ezeket térítésmentesen az egyházak polgárjogi jogképességét biztosító önfenntartó vallási egyesületek (association cultuelle) használatába adták. ${ }^{96} \mathrm{~A}$ katolikus egyház ezzel elveszítette közjogi személyiségét és közhatósági jellegét. A vallási egyesületek alakítását nyilvános vallásgyakorlás, a vallás fenntartása és az ezzel járó költségek előteremtése céljából tették lehetôvé az 1901. július 1-jei egyesületi törvényben foglaltaknak megfelelően. Vallási jelképeket nyilvános helyeken, középületeken nem lehet elhelyezni, kivéve a vallásgyakorlás céljára szolgáló épületeket, temetőket, múzeumokat. Az elismert és a nem elismert felekezetek közötti különbség tehát megszűnt, azaz egyenlő jogokat biztosítottak minden felekezetnek, amely az egyesületi formát elfogadta. A katolikus egyház elutasító hozzáállása miatt az 1907. január 2-i törvény lehetôvé tette azt is, hogy a nyilvános vallásgyakorlat az általános egyesülési törvény alapján szervezett formában történjen. Jogképességgel az ilyen egyesület is rendelkezett, belső szervezete tekintetében pedig nagyobb szabadság illette meg, mint a vallási egyesületeket. A laikusok egyházkormányzati jogát mereven elutasító katolikus egyház érdekeinek azonban ez a forma sem felelt meg. Kisegítő megoldásként a 4. cikkelyben rögzített lehetőséggel éltek: nyilvános vallásgyakorlásra a gyülekezési jog alapján, lelkészi meghívásra került sor. Amíg ugyanis az állam az egyházi épületek rendeltetését nem változtatta meg, azok a papság és a hívők rendelkezésére álltak. Ilyen módon a hierarchikus szerveződéstől idegen egyesülési alakzat felvétele elkerülhetô volt és a katolikus egyház csak papjai útján lépett az állammal összeköttetésbe.

A kortárs katolikus egyházjogtudomány az 1905. évi törvényt mindezek ellenére is egyházuk elnyomásaként, az egyházi ügyekbe való beavatkozásként értékelte. ${ }^{97}$ Az állam és az egyházak közötti viszonyt a vallástalan állam semlegessége jegyében rendező francia szabályozásban, melynek lényegi vonása a katolikus nemzeti egyház és az állam közötti összefonódás lebontásában ragadható meg, a többi felekezet mellékszereplő volt, akik a jogegyenlősítés jegyében ${ }^{98}$ léphettek ki forradalom előtti diszkriminált jogállásukból.

\footnotetext{
${ }^{94}$ GolDSCHMITT, Der Kulturkampf in Frankreich 44.

${ }^{95}$ Ennek elemzését lásd GOLDSCHMITT, Der Kulturkampf in Frankreich 57-61.

${ }^{96}$ BOCHKOR, Francia egyházpolitika 607-618.

${ }^{97}$ Lásd GOLDSCHMITT, Der Kulturkampf in Frankreich 61.

98 A protestáns egyházak vagyonának szekularizálása (1793. március 8-i dekrétum) illetve a napóleoni protestáns egyházszervezet vonatkozásában lásd RICHTER, Staats- und Gesellschaftsrecht II. 594-596.
} 


\title{
2.4. Kulturkampf és Maigesetze. A vilmosi Németország és az Osztrák Császárság egyházpolitikája
}

\author{
„Zsarnok Heródes, miért remegsz. / Krisztus jövetelére? / \\ Földi batalmat nem keres, / Ki mennyet hoz a földre. ${ }^{\$ 99}$
}

A német térség egyházpolitikája a 19. század második felében, a Nyugat-Európához képest mintegy 100-150 évvel megkésett polgári modernizáció során lényegét tekintve azonos irányvonal mentén alakult annak ellenére, hogy a Hohenzollern vezetéssel megvalósult kisnémet egység és az európai nagyhatalmi politikából egyre inkább kiszoruló Habsburg örökös tartományok két külön államalakulatot képeztek. Míg a megkésettség elsődleges oka jogtörténeti szempontból a tartományi széttagolódásban ragadható meg, a polgári modernizáció a korábbi, tartományi szintű kezdeményezésektől eltekintve akkor kerülhetett előtérbe, amikor - ha nem is egy, de két államba - integrálódott a német térség. A klasszikus liberális, francia-porosz felvilágosult hagyatékon alapuló és a konzervatív, túlnyomórészt katolikus impulzusok kötélhúzása jellemezte úgy az 1871 ben létrejött egységes német állam, mint 1867 után az Oszták-Magyar Monarchia nyugati felének hivatalos egyházpolitikáját az elsőben a liberális, a másodikban a konzervatív erők túlsúlyával. Az egyházak és az állam viszonyát érintő reformok - a polgári modernizáció államszervezeti és jogalkotási eredményeinek elismerése mellett is - erôs társadalmi vitát és egyházi kritikát váltottak ki az egyesület Németországban. Bár ilyen mértékű felzúdulás az osztrák egyházügyi liberalizáció nyomán nem történt, a vallási tradíciót képviselő katolikus egyház, amely a sikeresnek bizonyult ellenreformáció után az örökös tartományok lakosságának túlnyomó többségét ismét tagjai sorában tudhatta, társadalmi befolyása megőrzése érdekében szállt síkra.

A hasonlóság lényegét tekintve három történeti gyökérrel magyarázható. Először is a középkori Sacrum Romanum Imperium egységes egyházpolitikája kiterjedt a birodalom minden tartományára, így az 1282 után mintegy két évszázad alatt megszaporodó Habsburg örökös tartományokra is. Közvetlen módon ez a középkori hagyaték ugyan nem befolyásolta a 19. századi folyamatokat, de a jogtudatban és a birodalom átörökített intézményeiben fellelhetô a hatása. Másodszor említhető, hogy a protestantizmus - az ekkor már Német Nemzet Szent Római Birodalmának nevezett állam - minden territóriumában elterjedt. Igaz, hogy a Habsburg uralmi térségben az állami támogatást élvező rekatolizáció a 17. századra majdhogynem vallási homogenitást eredményezett, mégsem látni nagy különbséget a rendi államok monarchikus uniójának (1500-1749) tekintett örökös tartományok katolikus orientációja és a német tartományfejedelemségekben a fejedelem és a tartományi rendek által meghatározott római katolikus vagy evangelica augustana tartományi vallás között. Államvallásokról volt szó, minden más felekezettel szemben kizárólagos jelleggel mindkét esetben. A hasonló alkotmányjogi fejlődés okait keresve harmadikként az 1848. évi forradalmi hullám következtében megfogalmazott alkotmánytervezetek azonos szellemiséget képviselő elveiről kell említést tenni annak ellenére is, hogy a kremsieri tervezet I. Ferenc József félelmei és konzervativizmusa, a frankfurti alkotmány pedig a porosz uralkodó alulról szerveződő, demokratikus egységtörekvést elutasító hozzáállása miatt zátonyra futott.

\footnotetext{
${ }^{99}$ Coelius Sedulius alapján LUTHER: Az egyház babiloni fogságáról szóló könyvecske 113.
} 
A német jogterületen elsőként Johannes Althusius (1557-1638) természet- és észjogi tana által járult hozzá a szekuláris állam kialakításához közvetett, az emberi jogok történetéhez közvetlen módon. Egy generációval később Samuel von Pufendorf (1632-1694) elképzelései csak azt célozták, hogy az államhatalom jogos, önkénytôl mentes, a közjó érdekében elkötelezett és az objektív jogrendhez kötött hatalom legyen. A polgár nem jogalany volt, hanem az állami gondoskodás tárgya. Pufendorf és a porosz jogalkotásra a hallei egyetem kancellárjaként tényleges befolyást gyakorló Christian Freiberr von Wolf (1679-1754) az államtól nem követelte a természetes jogokat; a szabadság és az egyenlőség eszmerendszerükben csupán természetes állapot maradt. A német valóság, a teutsche Libertät messze elmaradt attól, amit Angliában a 17-18. század fordulójára a liberty jelentett. Az igazi szabadelvú gondolkodás német területen csak a 18. század utolsó harmadában bontakozott ki. A felvilágosodás szelleme átitatta az irodalmat, majd a francia forradalom hatására a jogászi gondolkodásban és az államjog területen is megjelentek az első nyomok. Az individuum autonómiájához - Immanuel Kant (1724-1804) szerint - hozzátartozott az ember szabadsághoz, egyenlőséghez és biztonsághoz való joga, amelyeket az államnak mindenkor tiszteletben kell tartani.

Modernizáció általában véve, de a felekezeti jogegyenlőség, vagy legalábbis bizonyos terjedelmú vallási türelem tekintetében is - a teutsche Libertät szellemében - csak tartományi szinten vált lehetségessé. Ezek a jogok szociális reformprogram részeként vagy a törvényhozás objektív alapelveként valósultak meg, az államcélnak megfelelő korlátozott módon. A bandenburgi választófejedelem, Hohenzollern Frigyes Vilmos - gazdasági szempontok által vezérelve - 1671-ben lehetővé tette a berlini zsidó hitközség megalapítását, Nantes-i Edictum visszavonása (1685) után pedig menedékjogot és kedvezményeket adott a francia hugenottáknak. Abban az évben, amikor a szabadkőműves Christian Wilhelm von Dohm Poroszországban $A$ zsidók polgárijavulásárólírt, ${ }^{100}$ II. József a Habsburg örökös tartományokban ugyancsak a vallási türelem (Toleranæpatent, 1781. október 13.)

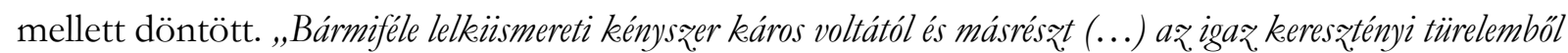
származó nagy nyereségtöl’"101 indíttatva lényegében a cuius regio, eius religio elv maradéktalan érvényesítéséről mondott le, amikor úgy döntött, hogy - bár a nyilvános vallásgyakorlást csak a római katolikus egyháznak engedélyezve - a két protestáns felekezetnek és a nem egyesült görög egyháznak lehetôséget biztosít a magán-vallásgyakorlásra. Imaházat (tehát nem templomot) az azonos helyen lakó, egy felekezethez tartozó száz család létesíthetett, torony, harang és utcai bejárat nélkül. A felekezeti jogegyenlőségről szó sem volt. A Voltaire tanaiban mérget látó katolikus uralkodó a kellő vallási türelem mellett továbbra is fenntartotta a katolikus egyház előjogait, bár ehelyütt nem részletezhető - egyházügyi rendelkezései, többek között a vegyes házasságokat és az abból származó gyermekek vallását szabályozó pátensei ${ }^{102}$ a katolikus érdekeket súlyosan sértették. ${ }^{103}$

\footnotetext{
100 A zsidó emancipációs törvény, melynek előkészítése elsősorban Wilhelm von Humboldt nevéhez köthető, Poroszországban a napóleoni háborúkat követő átfogó reformprogram részeként született meg 1812-ben. Mintegy 33 ezer főnyi porosz zsidó kapott ekkor állampolgárságot. Lásd DOHM, Über die bürgerliche Verbesserung der Juden passim; KATZ, Kifelé a gettóból 84-86.

101 Idézi BALTL - KOCHER - STEPPAN: Österreichische Rechtsgeschichte 179.

102 Herger, Polgári állam és egyházi autonómia 214-230.

103 A Habsburg örökös tartományok rekatolizálása 1628-ra befejeződött. A zsidókat az 1490-es évek végén BelsőAusztriá ból kiűzték, míg a többi tartományban korlátozott jogokkal ugyan, de megmaradhattak. A felvilágosult abszolutizmus transzmigrációt előtérbe helyező, majd a vallási tolerancia irányába fejlődő egyházpolitikájához lásd vON ARETIN, Die Konfessionen als politische Kräfte181-241; KOCHER, Die Reformen Josephs II. 137.
} 
A francia forradalmi csapatok katonai sikerei következtében 1795-ben a Rajna balparti területeket a Német-római Birodalomtól elcsatolták. A bazeli titkos szerződés értelmében Poroszország a területüket vesztett fejedelmek kárpótlását a katolikus egyházi vagyonból kényszerült megoldani. Az 1797-es campo formioi és az 1801-es luneville-i békében Franciaország ezt a megegyezést Ausztriára illetve magára a Német-római Birodalomra is rákényszerítette. Ennek értelmében a birodalmi gyúlés 1803. február 25-én a szekularizáció mellett döntött (Reichsdeputationshauptschluß). A birodalmon belül eddig tartományfejedelemségként (de facto önálló államként) funkcionáló kölni, a trieri és a mainzi választófejedelemségek, valamint 1 hercegérsekség, 19 hercegpüspökség és 80 apátság most világi kézre került illetve megszűnt, mint ahogy 200 kolostor és 18 egyetem is. Ezzel együtt mintegy 3 milliós római katolikus lakosság protestáns, azaz ekkor kifejezetten katolikus-ellenes közigazgatás alá került. ${ }^{104}$ A katolikus egyházi vagyon vesztesége 3 milliárd aranymárka értéket tett ki; ennek következtében az egyház oktatási és szociális hálózata összeomlott. ${ }^{105}$ A katolikus történetírás által sötét fényben láttatott korszakot erősen árnyalja, hogy nem sokkal késóbb, az 1810-20-as években kötött Consalvi-konkordátumok (1817: Bajorország, 1821: Poroszország, Baden, Würtemberg, Hessen-Darmstadt, Kurhessen és Nassau, 1824: Hannover) messzemenő jogokat biztosítottak az egyháznak a főpapi kinevezések, a püspökségek és káptalanok dotációja, az egyházmegyei kormányzás és az egyházi hierarchia újjászervezése terén is. ${ }^{106}$

Amikor 1815-ben a Német Szövetség az addigi birodalom helyén a bécsi kongresszuson létrejött, a jogállamiságot a kanti hagyaték értelmében a hatalmi viszonyok jogviszonnyá alakításával próbálták megvalósítani. A Deutsche Bundesakte (1815. június 8.) és a Wiener Schlussakte (1820. május 15.) jogkatalógusa, új nemzetközi jogi státust létrehozva, rögzítette a szövetséget alkotó fejedelmek és a szabad városok alattvalóinak jogait. Deklarálta, hogy „a Német Szövetség országaiban és területén a keresztény felekęretek között a politikai és polgári jogok élvęetében nem lehet különbség", sőt kifejezte szándékát, hogy a „zsidó vallást követö lakosoknak“"a szövetséges államokban „polgári kötelezettségeike.kel a polgári jogok élvezetét megteremtsék és biz̧tositsák. "olyan módon, hogy az egyes államokban már elismert jogaikat megtartják. ${ }^{107}$ A korai alkotmányosság ${ }^{108}$ ezen alkotmányai azonban a szabadságjogok objektív jellegét hangsúlyozták, és azok biztosítását a szuverén hatalmának teljességéből vezették le, mint ahogy ezt tette a bajor királyság 1808. május 1-jei alkotmánya (VII. cikkely) is, és messzemenően kerülték a természetjogi kicsengést.

A német alkotmányfejlődésben a eimari köztársaság koráig egyedülálló az 1848-49-as évek demokratikus egységszervezési kísérlettel összekötött alkotmányozása. A korai alkotmányosság termékeivel szemben a frankfurti nemzetgyúlés proklamálta a nép alkotmányozó hatalma útján lefektetett jogokat, amelyek alapja az emberi személyiség méltóságának és szabadságának a megőrzése volt. ${ }^{109} \mathrm{Az}$ 1848. december 17 -én kihirdetett, a „Német nép alapjogairól sqóló törvény “ néhány

\footnotetext{
${ }^{104}$ MORSEY, Wirtschaftlische und soziale Auswirkungen der Säkularisation in Deutschland 361-383.

105 ADRIÁNYI, A katolikus egyház helyzete 51.

106 ADRIÁNYI, A katolikus egyház helyzete 52.

107 Deutsche Bundesakte vom 8. Juni 1815, Teil II Art. XVI, http://www.verfassungen.de/de/de06-66/bundesakte15i.htm (2020. 07. 07.)

108 A polgári államépítési elvek megjelenését a német alkotmányozásban lásd OESCHEY, Montesquieu und die Verfassungen des deutschen Frühkonstitutionalismus 361-389.

109 Értékeléséhez lásd STRAuss, Staat, Bürger, Mensch, passim.
} 
későbbi kiegészítéssel az 1849. a március 28 -i birodalmi alkotmányába ${ }^{110}$ is bekerült (VI. cikkely: A német nép alapjogai) Ez az alkotmánytervezet messzemenő liberális szemlélettel rendezte a vallási jogviszonyokat. A törvény előtti egyenlőség elvéből természetes módon következett, hogy „minden németet megillet a lelkiismereti- és vallásszabadság teljes élvežete“. Ehhez tartozott az a szabadság is, hogy „senki sem kötelezhetō vallási meggyózódése nyilvánosságra hozatalára“ (144.S). Rögzítették, hogy „a németek közös házi és nyilvános vallásgyakorlása nem korlátoz̧ható"(145.\a.). Bár mindkét szakaszban elvileg teljes szabadságjogot ismert el a nemzetgyúlés, mégis úgy rendelkezett - a francia Emberi és Polgári Jogi Nyilatkozattal azonos módon, - hogy van egy egyedüli korlát, mégpedig „ę̧en szabadság gyakorlása során elkövetett büntettek és kihágások" esete, amikor „törvény szerint" büntetni kell (145.』 b.). A vallási diszkrimináció tilalmát, azaz hogy „a polgári és állampolgári jogok élvezete nem függhet és nem korlátozható bitvallás szerint", az állampolgári kötelezettségek teljesítésének korlátjával szabályozták (146.』).

Jogot kapott minden felekezet arra, hogy önállóan rendezze és igazgassa saját ügyeit, az állam általános törvényeinek megfelelően. Az egyházi autonómia teljes körü elismerése (147.』a.), amely megfelelt a német protestáns gyökereknek, feltételezte azt is, hogy ez a jog egyenlő módon és mértékben illet meg minden felekezetet, azaz „egy felekę̧et sem részesülhet a többivel szemben az államtól elönyökeben; továbbá államegybáz nem állhat fenn" (147.\$ b.). A rendkívül következetes, szabadelvü szabályozás legnagyobb értéke talán az a rendelkezés volt, hogy „uj vallásfelekezretek szabadon alakithatók, nincs szülkség hitvallásuk állami elismerésére" (147.』 c.). Tehát sem formai, sem tartalmi feltételt nem állítottak: nem kötötték a felekezet alapítását taglétszámhoz, iskola vagy istentisztelet céljára szolgáló helyiség meglétéhez, sôt a hitvallás írásos benyújtásához sem. Vallás tekintetében a szabadság teljességéből következett annak kinyilvánítása, hogy „senki sem kényszeritheto” egyházi szertartásra vagy ünneplésre“(148.』), és jelentősége volt a szakrális esküformula („Isten engem úgy segéljen”, 149.\$) lehetőségének is. Bár maga az alkotmány csak akkor bukott meg, amikor $I V$. Frigyes Vilmos a felkínált koronát visszautasította, az 1848. december 17-i törvényt, a nemzetgyülésben többségben lévő liberális erôk művét az újjáélesztett nemzetgyưlés 1851. augusztus 23-i döntése értelmében több állam (Bajorország, Hannover, Ausztria és Poroszország) is érvénytelennek tekintette magára nézve. A sikertelenség ellenére is fontos megemlíteni, hogy a többi szabadságjog mellett a vallásszabadság tartalmi elemeiként összegezhető vallási vonatkozású rendelkezések nem a francia előkép szerinti absztrakt jogok csupán, melyek érvényesítését 1789-ben semmi sem biztosította, hanem sokkal inkább az amerikai Bill of Rights mintájára ${ }^{111}$ megalkotott pozitívizált alkotmányos jogoknak tekinthetők, sajnos még joghatály nélkül.

Ha a német egység hiánya miatt a polgári alkotmányosság és államberendezkedés megvalósítása további késedelmet szenvedett is, bizonyos változások a tradicionálisan katolikus kötődésủ Ausztriában is bekövetkeztek. ${ }^{112} \mathrm{~A}$ francia forradalom és az amerikai alkotmányfejlődés elveinek hatására a Habsburg örökös tartományokban is erősödött a harmadik rend részéről a szabadságjogok iránti igény, majd 1815 után a nemességen belül is létrejött egy liberális csoportosulás, amely az állam és az egyház elválasztását és az egyház hatáskörének a lelki

\footnotetext{
110 Verfassung des Deutschen Reiches vom 28. März 1849, http://www.verfassungen.de/de/de06-66/verfassung48i.htm (2020. 07. 07.)

$111 \mathrm{Az}$ Amerikai Egyesült Államok alkotmányos értékeinek hatásához lásd FRANZ, Das Amerikabild der deutschen Revolution, passim.

112 Az 1848-1867 közötti korszak egyházpolitikai változásai tekintetében lásd MAYER-MALY: Die Grundrechte des religiösen Lebens 38-62.
} 
gondozásra való korlátozását tűzte ki célul. ${ }^{113}$ Bár a formális szempontból első ilyen jellegű dokumentumként számon tartott pillersdorfi alkotmány (1848. április 25. ${ }^{114}$ és az oktrojált olmützi alkotmány, valamint a hozzá csatolt alapjogi pátens (1849. március 4. ${ }^{115}$ egyaránt a századelő német korai alkományaihoz illetve az 1830. évi belga előképhez hasonlíthatók csak, az előbbi alapján összeült kremsieri (Kromeritz) birodalmi gyűlés alkotmánytervezetét ${ }^{116}$ a szakirodalom érett alkotmányos dokumentumként tartja számon. Annak ellenére, hogy a 19. századi alkotmányozás tipikus problémáitól ez sem mentes, a kremsieri tervezetben szerepelt először Ausztria történetében az a mondat, hogy „minden állambatalom a néptöl szármariłe (...)“. Az ebben szereplő alapjogok egy része, megváltozott tartalommal, tipikus koraalkotmányos vonásokkal, az alapjogi pátensbe is bekerült, de a leliismeret és a vallás szabadsága nem a birodalom egésze, csak a Ciszlajtán területek vonatkozásában nyert rögzítést. Gyakorlati jelentősége mindennek nem volt, hiszen alkotmánybíráskodás és végrehajtási normák hiányában valamennyi jog csak államcélmeghatározásként volt értelmezhető. ${ }^{117}$

A szilveszteri pátenssel (1851. december 31.) a koraalkotmányos korszak a vallási viszonyok tekintetében is véget ért. Az olmützi alkotmányhoz csatolt alapjogi pátenst formálisan is hatályon kívül helyezték, bár a törvényesen elismert egyházak azon jogát, hogy közös, nyilvános vallásgyakorlatot folytassanak és belső igazgatást végezzenek, nem vonták meg. A katolikus egyházat a kormányrendszer fontos részének tekintették. Az 1855. augusztus 18-i konkordátum, ${ }^{118}$ mellyel Ausztria ismét katolikus hatalomként lépett fel. Az eddig állami hatáskörben lévő teendők egész sorát adta át anélkül, hogy azok állami felügyeletét biztosította volna. Ennek jelentősége elsősorban az volt, hogy - erősen középkorias jelleggel - az egyház világi hatalmat gyakorolt és az állam feladta az egyházakkal szembe 1848-ban megfogalmazott indifferens magatartását. Külpolitikai vonatkozásban a konkordátum egyrészt a német katolikusok védelmét és ezzel Ausztria pozíciójának erősödését jelentette a német szövetségben, másrészt a francia hatás háttérbe szorítását is magával hozta, nem csak a német térség, hanem Szardínia, Spanyolország, Hollandia és Svájc vonatkozásában is. ${ }^{119}$

A frankfurti nemzetgyűlés és a kremsieri birodalmi gyúlés által megalkotott alkotmányjogi dokumentumok liberális szellemiségû rendelkezései a 1871 után az egységes német államban, illetve 1867 után Ausztriában finomabb megoldásokat követve, kompromisszumos jelleggel, de folytatásra leltek.

Az 1867. év a decemberi alkotmány öt alkotmánylevelével ${ }^{120}$ mélyreható változást hozott az Osztrák Császárságban. „Az állampolgárok általános jogairól“ szóló második alkotmánylevél,

113 REINHOLD, Schwarzgelber Patriotismus 372-377.

114 Allerhöchstes Patent vom 25. April 1848 Verfassungs-Urkunde des österreichischen Kaiserstaates, III. Staatsbürgerliche und politische Rechte der Staatseinwohner, http://www.verfassungen.de/at/verfassung48-i.htm.

115 Reichsverfassung für das Kaisertum Österreich vom 4. März 1849 nebst dem dazu gehörigen Manifeste und Grundrechtspatent, http://www.verfassungen.de/at/verfassung49-i.htm (2020. 07. 07.)

${ }^{116}$ Entwurf des Österreichischen Reichstages, welcher in der Zeit vom 22. Juli 1848 bis 4. März 1849 getagt hat, zuerst in Wien, ab dem 22. November 1848 in Kremsier (Mgft. Mähren), http://www.verfassungen.de/at/verfassungsentwurf49-i.htm (2020. 07. 07.)

117 BRAUNEDER, Osztrák alkotmánytörténet 147-148.

118 HuSSAREK, Die Verhandlungen des Konkordats 477-811.

${ }^{119}$ LEISCHING, Die römisch-katholische Kirche in Cisleithanien 33.

120 Staatsgrundgesetze des Kaisertums Österreich vom 21. Dezember 1867, http://www.verfassungen.de/at/ (2020. 07. 07.) 
melynek szövegezését a kremsieri tervezet és az olmützi alkotmányhoz csatolt alapjogi pátens is erősen befolyásolta, ismét az állam és az egyház elválasztásának elvén állt. Míg az ellenreformáció korát az osztrák katolikus egyház az ecclesia triumphans pozíciójában zárta, és államegyházi jogállását a felvilágosult egyházpolitikai reformok sem veszélyeztették, most a polgári modernizáció jegyében a liberális elvek kerültek ismét előtérbe. 1861. évi protestáns pátens az evangélikus egyháznak köztestületi jogállást biztosított, majd, mivel a katolikus egyházat privilegizáló konkordátumot külpolitikai szempontból még meggyőződéses neoabszolutista hívek is sérelmesnek találták Ausztriára nézve, 1867-ben a birodalmi tanács elrendelte annek revízióját. ${ }^{121}$ Ezt az utat folytatta a második alkotmánylevél, amikor garantálta az állampolgárok lelkiismereti és vallásszabadságát, a törvényesen elismert vallási testületek nyilvános vallásgyakorláshoz és autonóm igazgatáshoz való jogát, valamint a törvényesen el nem ismert vallási testületeknek a magán vallásgyakorlathoz való jogát. A vallásos hit megválasztásának szabadságát (személyes vallásszabadság) tehát minden állampolgár élvezhette, a közösségi vallásgyakorlás azonban messzemenően korlátozott volt.

Az elveket rögzítő decemberi alkotmány végrehajtásáról 1868. május 25-én három törvénycikkben rendelkeztek. Az ún. májusi törvények (Maigesetre) közül az első a házassági törvény volt, amely ismét hatályba helyezte az OPTK házassági köteléki jogát és bevezette a szükségbeli polgári házasság (Notzivilehe) intézményét arra az esetre, ha a lelkész egy felekezeti jogban, nem pedig az OPTK-ban meghatározott házassági akadály (pl. vegyesházasság) esetén megtagadja a közremúködést a házasságkötésnél. ${ }^{122} \mathrm{~A}$ második az oktatás és az egyházak közötti kapcsolatot rendezte. Az állam általános felügyeleti joga alapján tartományi, kerületi és helyi iskolatanácsok felállításáról rendelkeztek, és a vallásoktatást az iskolafenntartó egyházaknak engedték át. ${ }^{123} \mathrm{~A}$ harmadik törvény az állampolgárok interkonfesszionális viszonyairól szólt, mely 14 éves kor felett biztosította a vallásváltoztatás szabadságát. A liberális, de messze nem egyházellenes szellemiségú, jogilag jól átgondolt, érezhetően nagy gondossággal megfogalmazott törvények célja az állami és az egyházi szféra világos elválasztása volt olyan módon, hogy a katolikus egyházat a többi felekezettel szemben előnyben részesítették. Ennek ellenére, vagy mondhatnánk, talán éppen ezért, a katolikus egyház kártékonynak ítélte úgy az alkotmány vallási vonatkozású rendelkezéseit, mint a májusi törvényeket. Az I. vatikáni zsinat pápai tévedhetetlenséget (infallibilitas) kimondó dogmája, valamint a konkordátum életben tartása körüli vita az egyház kritikusainak számát növelte, a kormányzat békülékeny hozzáállása és a császár fáradozása azonban elkerülhetôvé tette a komolyabb ellentétek kibontakozását. ${ }^{124}$

Ilyen előzmények után a májusi törvények elnevezés (ez esetben is három törvéyről volt szó) még egyszer előkerült az Osztrák Császárságban. A katolikus egyház külső viszonyainak szabályozásáról címet viselő 1874. május 7-i törvény megerősítette a konkordátum 1870. évi hatályon kívül helyezését, illetve rendezte az egyház vagyoni viszonyait. Ugyan ezen a napon fogadták el a vallási alapról szóló törvényt, amely a II. József által a feloszlatott klostorok vagyonából

\footnotetext{
${ }^{121}$ ENGEL-JÁNOSI, Österreich und der Vatikan 130.

122 Ehhez csatlakozva állami anyakönyvvezetést vezetett be az 1870. április 9-i törvény.

${ }^{123}$ Az 1869. május 14-i birodalmi népiskolai törvény ez alapján általános tankötelezettségről rendelkezett. 1883-tól az iskola vezetőjének képesítést kellett szereznie annak a vallásnak az oktatására, melyhez öt éves átlagban a tanulók többsége tartozott. Lásd BALTL - KOCHER - STEPPAN: Österreichische Rechtsgeschichte 234.

${ }^{124}$ Az 1868. évi májusi törvényeket követő egyházi ellenálláshoz lásd MIKO, Die katholische Kirche in ÖsterreichUngarn 211-222.
} 
létrehozott vallási alapot állami vagyonnak nyilvánította. Végezetül a harmadik májusi törvény (1874. május 20.) a mindeddig el nem ismert felekezetek számára megadta a törvényi elismerést, amennyiben nem álltak szemben a szokásokkal és törvényekkel, valamint önálló közösséget alkottak.

Ezek voltak az osztrák, alapvetôen liberális, de a katolikus egyházzal szemben mindvégig megfontolt, előzékeny politikát folytató polgári modernizáció eredményei az állam és az egyház viszonyát tekintve. A tradicionális katolikus elkötelezettség, a lakosság túlnyomó részt homogén vallási hovatartozás és az 1848-as forradalmi eszmék lecsengésével önmagát ismét a középkorias „Gottesgnadentum" fényében látó Ferenc József személye (az Isten kegyelméből történő uralkodás hangsúlyozása a népszuverenitással szemben) ${ }^{125}$ garantálta ezt az összességében békés átalakulást. A porosz-német kultúrharchoz fogható ellentétet a Monarchia sikeresen elkerülte; gróf Andrássy Gyula külügyminiszter ennek érdekében nem támogatta Bismarckot a pápai hatáskör visszaszorítására irányuló törekvésében sem. Az 1868. évi és az 1874. évi liberális egyházpolitikai rendelkezések által megrendített pozíciójú osztrák katolikus egyház a 70-es évekközepétől a belpolitikai életben előtérbe kerülő konzervatív-klerikális és nemzeti erőktől, a századvéghez közeledve pedig az immár párttá szerveződött - nem ritkán zsidóellenes ${ }^{126}$ - politikai katolicizmustól remélt segítséget.

A visszafogott osztrák egyházpolitikai liberalizációt eszközeit és hozzáállását tekintve messze meghaladta a porosz utat követő össznémet egyházi reformok köre. Az az erős ösztönző erő, amely 1848-ban az alapjogok alkotmányos rögzítéséhez vezetett az alulról szerveződő német egységtörekvés során, jóideig nem jelent meg újra. Kivételt jelentett az 1850. január 31-i porosz alkotmány, amely a vallási viszonyokról két, egymástól jelentôsen különböző rendelkezést tartalmazott: liberális szellemben az egyéni hitvallás megválasztásának szabadságát és a polgári jogok élvezetének hitvallástól független voltát biztosította (12. §). Sokkal inkább a 16. század óta kialakult tradicionális német rendet követte azonban azzal, hogy csak a római katolikus és az evangélikus egyház számára adta meg az önálló egyházi igazgatáshoz való jogot, valamint a vallási, oktatási és jótékonysági célokat szolgáló intézmények és alapok biroklásának továbbá élvezetének jogát. Ezzel együtt az államnak az egyházi hivatalok betöltéséhez illetve megerôsitéséhez fűződő

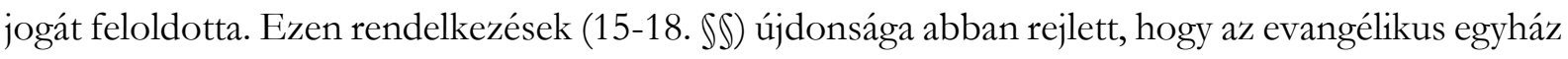
szervezete mindeddig nem épülhetett ki hiánytalanul, hiszen a 16. század óta az államhatalom mélyen beavatkozott az egyház belső ügyeibe. A katolikus egyház vonatkozásában az 1794-ben hatályba léptetett természetjogi, de kompromisszumos karakterű általános porosz törvénykönyv (ALR) az állammal szemben erôsen korlátozott jogokat biztosított csak. Ezek a korlátok többnyire filozofikus követelmények, nem konkrétan érvényesülő jogi normák voltak; sem az egyház, sem az állam nem érvényesítette őket. ${ }^{127} \mathrm{Az}$ 1840-ben trónra lépő $I V$. Frigyes Vilmos úgy az evangélikus, mint a katolikus egyház tekintetében messzemenően támogatta azok önállóságát. A fenti alkotmányos rendelkezések életbe lépte ennek a szemléletmódnak volt köszönhető.

\footnotetext{
125 Ferenc József az 1874. évi májusi törvényekkel szemben mindvégig visszafogott hozzáállást tanúsított. Lásd hozzá FELLNER, Kaiser Franz Joseph und das Parlament 287-347.

126 Az osztrák zsidók jogállásához illetve önmeghatározásához a 19. század második felében lásd BIRNBAUM, Die nationale Wiedergeburt des jüdischen Volkes, passim; BIRnBaum, Den Ostjuden ihr Recht! passim; BLuM, Aufklärung und Reform bei den Wiener Juden, passim.

127 VON KIRCHMANN, Der Kulturkampf in Preußen und sein Bedenken 4.
} 
Az észak-német szövetség alkotmánya ${ }^{128}$ és ennek nyomán a birodalmi alkotmány ${ }^{129}$ nem rendelkezett az alapjogokról. Mindezt csak részlegesen kompenzálta az elképzelés, hogy a külön törvények útján gondoskodnak az alapjogok érvényesítéséről. Az 1869. július 3-i törvény, amely a polgári és állampolgári jogok között külön nevesítve a felekezetek jogegyenlőségéről rendelkezett a közhivatalok viselésére való képesség vonatkozásában, minden esetre az egyesült Németországban is hatályban maradt - „Vilmos, Isten kegyelméböl a poroszok királya” akaratából. A törvény preambuluma szerint az uralkodó legitimitását kizárólag Isten kegyelméből származtatta, ami különösen annak fényében érdekes, hogy a katolikus Habsburg-ház már jó kétszázötven éve hangoztatta véleményét, amely szerint a protestáns hitre tért Hohenzollernek elveszítették hatalmuk természetfeletti alapját: a fadarabból baltával hasított királyi pálca az angyaloktól átvett jogarral nem vetekedhet. ${ }^{130}$

Az alapjogok alkotmányi hiánya némiképp magyarázható azzal, hogy a 19. század második felében uralkodó jogi pozitivizmus értelmében a polgárok szabadságát akkor látták biztosítva, ha az ex act rögzítésen túl gyakorlati érvényesülésük garanciáit is megteremtették. Ez pedig - az alkotmány, mint jogi norma sajátosságából fakadóan - részleteit is tekintve külön törvények útján lehetséges. Nem feledhető azonban a vilmosi Németország kompromisszumos karaktere sem; az a törekvés, hogy a tradicionális elit és a feltörekvő polgárság közötti egyensúly megmaradjon. ${ }^{131} \mathrm{Az}$ egységes német nemzetállam vezetésének az egyházpolitika terén olyan problémával kellett megküzdenie, amely a vesztfáliai békekötések által rögzített vallási széttagolódásból következett. Míg a Habsburg örökös tartományokban ez a nehézség fel sem merült, hiszen a vallási térkép ott túlnyomórészt egyszínű volt, az eddig katolikus tartományfejedelem alatt álló dél-német tartományoknak az új föderatív államba való integrálása az egyházpolitika területén nem volt zökkenőmentes. A porosz hagyaték az egyházi ügyekbe erőteljesen beavatkozó, protestáns, de felvilágosult hozzáállásból és gazdasági érdekből fakadóan - toleráns egyházpolitika volt. Nos, 1871 után nem csak a nemzeti kisebbségek és a balliberális polgárság, hanem a német katolicizmus is ellentétbe került az államhatalommal, amikor a birodalmi jogegység létrehozása érdekében Bismarck kancellár (1871-1890) továbbra is fenntartotta szövetségét a polgári-nemzeti liberális erőkkel. ${ }^{132} \mathrm{~A}$ kor egyházjogi irodalma a bismarcki egyházpolitika a gyökerét egyértelműen az 1848-as eszmékben vélte felfedezni, ${ }^{133}$ míg a pápai tévedhetetlenségrôl szóló dogma kihirdetését csak közvetlen kiváltó oknak tekintették.

A kultúrharc (Kulturkampf) elnevezés Rudolf Ludwig Karl Virchow ${ }^{134}$ szabadelvű képviselőtől származik, aki ez alatt a kultúrának az egyházi befolyástól való felszabadítását értette. Ennek

128 Verfassung des Norddeutschen Bundes vom 16. April 1867, http://www.verfassungen.de/de/de6718/verfassung67-i.htm (2020. 07. 07.)

129 Gesetz betreffend die Verfassung des Deutschen Reiches vom 16. April 1871, http://www.verfassungen.de/de/de67-18/verfassung71-i.htm (2020. 07. 07.)

130 KOCHER, Szimbólumok és jelek a jogban 79.

131 WAHL, Der preußische Verfassungskonflikt 171-194.

132 PIKART, Die Rolle der Parteien im deutschen konstitutionellen System 237-257. és 258-281.

${ }^{133}$ KRABBE, Wider die gegenwärtige Richtung des Staatslebens im Verhältniß zur Kirche 4-5.

134 Virchowot a modern patológia tudományának megalapozójaként tartják számon. Liberális polititkusként részt vett 1848-ban a márciusi forradalomban, majd 1861-ben a Haladás Párt alapítója és elnöke lett. 1880 és 1893 között képvielő volt a birodalmi gyúlésben, elsősorban liberális egyházpolitikai és az antiszemitizmust elítélő hozzáállásáról volt ismert. Lásd ACKERKNECHT, Rudolf Virchow, passim. 
ellenére a fogalom az egyházellenesnek tartott állami jogalkotás szinonimájává vált. A német püspöki kar 1871 szeptemberében feliratban tiltakozott a császárnál, mivel a kormány nem távolította el azokat az iskolai hitoktatókat, akik az I. vatikáni zsinat új dogmájával szembehelyezkedtek. Míg a magas klérus a pápai tévedhetetlenség általános elismertetésén fáradozott, a kormányzati értékelés túlzónak találta a népiskolai oktatásra IX. Pius Quanta Cura (1864. december 8.) enciklikája értelmében gyakorolt egyházi hatást: a tanárok erôsen függtek az egyháztól és az oktatás a világi tárgyak esetében is ultramontán szemlélet szerint történt, ${ }^{135}$ ami a felekezetek közötti békés viszonyt is veszélyeztette. Az állami szuverenitás teljességének igényére hivatkozva 1872 februárjában az elemi iskolák felügyeletét átruházták az államra, majd az országból kiutasították a jezsuitákat és rövidesen az összes iskola állami felügyelet alá került. A dél-német tartományok ún. poroszosítása ellen fellépő egyházi vezetők és a katolikus Centrumpárt ezután egy reform-törvénycsomaggal szembesült. 1873. május 11-én az egyházi személyek képzéséről és alkalmazásáról, ${ }^{136}$ május 12-én az egyházfegyelmi hatalomról és az egyházi ügyekben eljáró királyi törvényszékek felállításáról, ${ }^{137}$ május 13 -án az egyházi büntető és fenyítő eszközök használatához való jog korlátairól, ${ }^{138}$ végül május 14 -én az egyházból való kilépés tárgyában ${ }^{139}$ rendelkezett a birodalmi gyűlés. A porosz kormány egyházpolitikáját hívei az állami szuverenitás teljességének igényéből kiindulva „a római bierarchia és az ultramontanizmus” létével ${ }^{140}$ indokolták, amely az ,utóbbi francia-német háború, (...) közvetett módon a protestantizmusnak a katolikus egyház. feletti gyözelme óta (!) politikai jelentöségre tett szert”, különösen annak fényében, hogy „miután az. Olasz. Királyságot az, európai hatalmak elismerték, a pápa világi hatalma Róma egy részére korlátozódott”. ${ }^{141}$

Katolikus részről azonban értetlenkedéssel fogadták azt, hogy Bismarck egy zsinati határozatnak az európai államok és különösen Németország vonatkozásában oly nagy jelentőséget tulajdonított. ${ }^{142}$ Hozzáállását durva keresztényellenességnek, vallástalanságnak bélyegezték, ${ }^{143}$ főleg az után, hogy a porosz, 1873. évi májusi törvények a klerikusokra is kiterjesztették az állami felügyeletet. 1873-ban a katolikus szerzők a „fegyverek” ismerete alapján már az ultramontán szemlélet elkerülhetetlen vereségéről vizionáltak, ${ }^{144}$ kifejezték azt is, hogy ez a vereség, azaz a katolikus vallásosság háttérbe szorítása általános morális bukást fog eredményezni: „(...) ha a barc véget ér, még ijesztốbb, sötétebb jövő elótt fogunk állni, és a gyö̃tes csak saját bukásán munkálkodott”. ${ }^{145} \mathrm{~A}$

\footnotetext{
135 VON KIRCHMANN, Der Kulturkampf in Preußen und sein Bedenken 9.

136 Gesetz über die Vorbildung und Anstellung der Geistlichen vom 11. Mai 1973. A törvény szövegét közli VON OESTFELD, Die kirchenpolitische Reformgesetze Preußens 47-69.

137 Gesetz über die kirchliche Desciplinargewalt und die Errichtung des Königl. Gerichtshofes für kirchliche Angelegenheiten vom 12. Mai 1873. A törvény szövegét közli vON OESTFELD, Die kirchenpolitische Reformgesetze Preußens 85-104.

${ }^{138}$ Gesetz über die Grenzen des Rechts zum Gebrauch kirchlicher Straf- und Zuchtmittel vom 13. Mai 1873. A törvény szövegét közli VON OESTFELD, Die kirchenpolitische Reformgesetze Preußens 104-109.

${ }^{139}$ Gesetz, betreffend den Austritt aus der Kirche vom 14. Mai 1873. A törvény szövegét közli vON OESTFELD, Die kirchenpolitische Reformgesetze Preußens 123-131.

140 Az ultramontanizmus szerepének értelmezéséhez katolikus részről lásd VON FLORENCOURT, Ueber die Stellung und die Maßnahmen der Staatsregierung gegenüber dem Ultramontanismus 10-12. és 102-104.

141 A hivatalos érvelést lásd vON OESTFELD, Die kirchenpolitische Reformgesetze Preußens 1-2.

142 VON KIRCHManN, Der Kulturkampf in Preußen und sein Bedenken 5.

${ }^{143}$ FABRI, Staat und Kirche. Betrachtungen zur Lage Deutschlands in der Gegenwart 21-35.

144 WeBER, Staat und Kirche nach der Zeichnung und Absicht des Ultramontanismus III.

145 VON FlORENCOURT, Ueber die Stellung und die Maßnahmen der Staatsregierung gegenüber dem Ultramontanismus 103.
} 
reformtörvény-csomag által kiváltott ellenállás mértéke minden esetre meglepetésként érte a porosz kormányt, nem különben az is, hogy IX. Pius pápa a következő év február 5-én kiadott enciklikájában az 1873. évi porosz májusi törvényeket a katolikusokra nézve érvénytelennek nyilvánította. ${ }^{146} \mathrm{~A}$ kultúrharc 1875. február 6-án a kötelező polgári házasságkötés bevezetésével érte el a tetôpontját. Az egyházi hatáskör csökkentése mellett ez a reform a felekezetek közötti kapcsolatot is elnehezítette azzal, hogy a törvény a protestáns felekezeti jog szabályait vette át szekularizált formában. Ugyanekkor betiltották a szószékről folytatott politikai aggitációt, állami felügyelet alá helyezték a papi szemináriumokat, sôt az állami ügykörnek tekintett egyházi vagyonkezelést olyan módon szabályozták, hogy az állami hatóságoknak szorosan alárendelt, laikus hivatali szervezet révén a szervezett egyházközség (közgyűlés, képviselőtestület, elöljáróság) intézményét meghonosították a porosz katolikus egyházban. A munkásmozgalom megerősödése miatt a kultúrharc azonban lassan lekerült a napirendről, majd az 1870-es évek végére a politikai katolicizmus megerősödésével és az egyházpolitika átrendeződésével be is fejeződött. A kormánynak szüksége volt immár a katolikus Centrumpárt támogatására, sốt a munkásmozgalomra reagáló keresztényszocializmus kibontakozását is megnyugvással vette.

\section{Modellkövető modernizáció?}

1892. május 19-én a magyar országgyülés képviselőházában gróf Csáky Albin vallás- és közoktatásügyi miniszter - a vegyes házasságból született gyermekek részére részleges polgári anyakönyvezés bevezetését tervbe véve - az állam és az egyház közötti kapcsolat formáit elemezte. A „vallásfelekezeti” és a „vallás nélküli” állam közötti átmeneti kategóriaként kora magyar rendszerét említette, amely szerint az állam a felekezetek felett áll, de nem ideológia nélküli, és azon iparkodik, hogy a felekezetek érdekeit egymással egyeztesse. Látta a kor kívánalmait és azokat az ellentmondásokat, amelyek a polgári jogegyenlőség elvével szemben ekkor fennálltak, épp ezért maga e három forma közül az amerikai megoldást tekintette ideálisnak, a vallás nélküli államot, ahol a törvényhozás, illetve a bírói jogalkalmazás kompetenciája csupán arra terjed ki, hogy a határvonalakat meghúzza annak érdekében, hogy aki él a lelkiismereti- és vallásszabadság jogával, az ne okozzon másnak jogsérelmet. ${ }^{147}$

A régóta esedékes egyházügyi modernizáció előtt álló magyar államban a kormánypárti szabadelvú és ellenzéki képviselôk szeme elôtt - a képviselőházi naplók tanúsága szerint - a nyugateurópai és az amerikai példák álltak, amelyeket ki követendő, ki elrettentő példaként említett hozzászólásában. Nemcsak az 1890-es évek elején volt ez így; ha egyházi kérdések kerültek napirendre, a modernizáció sürgetői a reformkorban és a kiegyezést követően is a polgárosodott nyugati társadalmakra, elsősorban az Amerikai Egyesült Államokra utaltak. Példának okáért a képviselők 1870. január 21-tôl március 17-ig terjedő 45 országos ülésén Franciaország és NagyBritannia után harmadik helyen az Amerikai Egyesült Államok állt 31-szeri idézettséggel. E hivatkozások nagy része Franciaország és Nagy-Britannia estében a modern államépítési elvekre, az Egyesült Államok esetében azonban kifejezetten az egyházi kérdésekre vonatkozott.

\footnotetext{
${ }^{146}$ Lásd VON KIRCHMANN, Der Kulturkampf in Preußen und sein Bedenken 19.

${ }^{147}$ Képviselőházi Napló II. 56. országos ülés.
} 
Figyelemre méltó, hogy a német térség egyházi viszonyait ekkor, 1870 elején nem volt szokás példaként említeni. Az egységes Németország maga is számos vallási-felekezeti problémával küzdött. IX. Pius pápa már idézett Quanta Cura kezdetű enciklikája (1864. december 8.), amelyhez csatolták az általa tévesnek ítélt nézetek listáját, majd az I. vatikáni zsinaton 1870. július 18-án elfogadott pápai primátus, valamint az infallibilitás (a pápa tévedhetetlensége hit és erkölcs dolgában) dogmája elnehezítette az állam és a katolikus egyház közötti kapcsolatot akkor, amikor az eddig katolikus fejedelmi hatalom alatt álló délnémet tartományok most tagállamként a birodalmi integráció és a jogegység szempontjából amúgy is ellentétbe kerültek a protestáns, porosz vezetésű szövetségi állammal. Tagadhatatlan, hogy a magyar egyházi viszonyok alakulását a földrajzi közelség, a nyugati politikai és jogi kultúrához való csatlakozás és felzárkózás igénye, majd a 16. századtól fogva - a Habsburg-házi uralkodók - miatt még inkább szoros politikai kapcsolat következtében számos tekintetben a német földön ismert intézmények befolyásolták. Mégis, a 19. század második felében az állam és az egyházak közötti viszonynak a modern polgári államhoz való igazítása területén a megkésett német modernizáció a magyar politikai elit számára nem kínált követendő mintát.

A francia egyházi viszonyok ez idő tájt képlékenyek voltak. A 18. század végén a radikális, minden tradíciót félresöprő ideológiai és államszervezeti átalakítást sok tekintetben visszarendeződés követte; az állam és az egyházak közötti viszony alapvetően a rendszerváltások jellege szerint, a köztársasági, illetve monarchikus államformához igazodva alakult. Ennek megfelelően a III. köztársaság (1870-1939) törvényhozása liberális hullámot jelentett, de a vallástalan állam semlegességének álarca mögé bújó, lényegét tekintve egyházellenes - francia modell csak a magyar egyházügyi modernizációt követően, 1905-ben nyert végleges formát.

Angliában a vallási tradíció, a katolikus, majd 1534 után az anglikán nemzeti egyház erősebbnek bizonyult, mint a 17-18. század fordulójára kibontakozó alkotmányos monarchia egyébként polgári elvei. Az egyházi viszonyok modernizálására a felekezeti jogegyenlőség jegyében csak a klasszikus liberális korszakban, a 19. század második felében kerülhetett sor, ekkor is olyan módon, hogy a Body Politic karjaként funkcionáló anglikán egyház megőrizte államegyházi jogállását.

Magyarországon a 16. századot követően a lakosság felekezeti hovatartozása heterogén összképet mutatott. Míg a dél-európai országok, Franciaország, a délnémet fejedelemségek és az osztrák örökös tartományok katolikus orientációja, valamint az észak-európai periféria lutheri és Anglia anglikán protestáns államegyházisága néhány kivételtől eltekintve homogén színben tűnt fel a vallási térképen, nálunk a felekezeti pluralizmus sajátos következményekkel járt. A vallás megválasztásának és a közösségi vallásgyakorlásnak a szabadsága mindig is akkor vált időszerű kérdéssé, mikor egy állam mindaddig egységes egyházi viszonyaiban szakadás következett be. Gondolhatunk itt Luther követőinek kiválására a katolikus egyházból, a puritán munkalázban égő Cromwell egyházpolitikájára, az antiklerikalizmus és az ész kultusza által befolyásolt francia forradalmi hevületre, vagy társadalmi támogatásából az 1850-es évekre sokat veszítő anglikanizmusra. De gondolhatunk arra is, hogy Észak-Amerikában a 13 keleti parti angol gyarmat az anyaországtól való függetlenedés után a vallási sokszínűség következtében alakított ki olyan föderális alkotmányjogot, amelyben az állam egy felekezetet sem részesíthet(ett) előnyben a többivel szemben. 
Úgy tűnik, ez a vallási sokszínűség az oka annak, hogy a magyar liberális reformhullámok idején, a reformkorban, illetve az 1890-es években erre az ekkorra letisztult és múködőképes amerikai modellre a magyar szabadelvű politikai elitt ${ }^{148}$ rendszerint utalt az egyházügyi modernizáció tekintetében. Nem jogátvételről, nem is közvetlen hatásról beszélünk: hivatkozási alapról van szó, olyan útról, amely a polgárosodásban megkésett Magyarország számára példaként szolgált és kívánatosnak tűnt.

\section{Felhasznált irodalom és források}

ACKERKNECHT, Erwin-Heinz: Rudolf Virchow. Arzt, Politiker, Anthropologe. Stuttgart 1957

ADRIÁNYI Gábor: A katolikus egyház helyzete Itáliában, Franciaországban, Németországban és Magyarországon a XIX. században. In: BÁRDOS István - BEKE Margit (szerk.): Egyházak a változó világban. Esztergom 1991, 509-512.

Alderman, Ellen - Kennedy, Carolin: A nép nevében. Az Amerikai Alkotmány kétszáz éve. Budapest 1993

vON ARETin, Karl Otmar Frhr.: Die Konfessionen als politische Kräfte am Ausgang des alten Reiches. Ein Beitrag zur Problematik der Reichsauflösung. In: Festschrift Joseph Lortz. II. köt., Baden-Baden 1957, 181-241.

BALTL, Hermann - KOCHER, Gernot - STEPPAN, Markus: Österreichische Rechtsgeschichte. Von den Anfängen bis zur Gegenwart. Graz 2008

BeTHeLL, Denis L. T.: English Black Monks and Episcopal Elections in the 1120s. English Historical Review 1969/84. sz. 673-698.

BIRNBAUM, Nathan: Die nationale Wiedergeburt des jüdischen Volkes in seinem Lande als Mittel zur Lösung der Judenfrage. Ein Appell an die Guten und Edlen aller Nationen. Wien 1893

BIRnBAUM, Nathan: Den Ostjuden ihr Recht! Wien 1915

BLuM, Kopel: Aufklärung und Reform bei den Wiener Juden. Phil Diss. Wien 1935

BOCHKOR Mihály: Francia egyházpolitika. Kolozsvár 1905

BŐDY Pál - URBÁN Aladár (szerk.): Szöveggyüjtemény az Amerikai Egyesült Államok történetéhez, 1620-1890. Budapest-Pécs 2001

Brauneder, Wilhelm: Osztrák alkotmánytörténet napjainkig. Pécs 1994

COTTRET, Monique: Jansénismes et Lumières. Pour un autre XVIIIè siècle. Paris 1998

DALlimore, Arnold A.: Georges Whitefield. Wheaton 1990

DaYTON, Donald W.: Theological Rotts of Pentecontalism. The Scarescrow Press 1987

VON DOHM, Christian Wilhelm: Über die bürgerliche Verbesserung der Juden I-II. Berlin 1781 és 1783

Dussian, Allison M.: Ghost Dance and Holy Ghost: The Echoes of Nineteenth-Century Christianisation Policy in Twentieth-Century Nativ American Free Exercise Cases. Stanford Law Review, 1997/4. sz. 774-776.

Endelman, Todd M.: Disraeli's Jewishness Reconsidered. Modern Judaism - A Journal of Jewish Ideas and Experience, 1985/5. sz. 109-123.

ENGEL-JÁNOSI, Friedrich: Österreich und der Vatikan 1846-1918. Band II, Graz - Wien - Köln 1958

FABRI, D. Friedrich: Staat und Kirche. Betrachtungen zur Lage Deutschlands in der Gegenwart. h.n. 1872

FELLNER, Fritz: Kaiser Franz Joseph und das Parlament. Materialien zur Geschichte der Innenpolitik Österreichs in den Jahren 1867-1873. In: Mitteilungen des Österreichischen Staatsarchivs 1956/9. sz. 287-347.

VON FLORENCOURT, Franz: Ueber die Stellung und die Maßnahmen der Staatsregierung gegenüber dem Ultramontanismus. Bonn 1872

FRAKNÓI Vilmos: Az egyházi javak saecularisatiója Franczia-Spanyol- és Olaszországban. Pest 1872

FrANZ, Eckhart G.: Das Amerikabild der deutschen Revolution von 1848/49. Zum Problem der Übertragung gewachsener Verfassungsformen. Heidelberg 1958

FrIEDBERG, Emil: Gränzen zwischen Staat und Kirche und die Garantien gegen deren Verletzung I. Tübingen 1872

Freedom, Thomas: Church and State in America to the Passage of the First Amendment. New York 1986

148 KAJTÁR, A 19. századi modern magyar állam- és jogrendszer alapjai 39-47. 
GALLAI Sándor: A Legfelsőbb Bíróság szerepe az Egyesült Államokban. Jogtudományi Közlöny, 1994/2. sz. 63 -82. GILCHRIST, John The Social Doctrine of John Wyclif. Canadian Historical Association, Historical Papers 1969, 157165.

GolDSCHMiTT, Fr.: Der Kulturkampf in Frankreich. Metz 1915

HiNZE, Otto: Wesen und Wandlung des modernen Staats. In: Staat und Verfassung. Gesammelte Abhandlungen zur allgemeinen Verfassungsgeschichte. Göttingen 1962, 470-496.

HALÉVy, Léon: Résumé de l'histoire des juifs modernes. Paris 1828

Herger Csabáné: Polgári állam és egyházi autonómia a 19. században. Budapest 2010

HERGER Csabáné: A nővételtől az állami anyakönyvvezetőig. A magyar házassági köteléki jog és az európai modellek. Budapest - Pécs 2006

HERGER Csabáné: Szakrális kontra szekuláris értékek a polgári modernizáció korában. Díké 2017/1. sz. 33-44.

VON HusSAREK: Die Verhandlungen des Konkordats vom 18. August 1855. Ein Beitrag zur Geschichte des österreichischen Staatskirchenrechts. In: Archiev für Österreichische Geschichte 1922/109. sz. 477-811.

KAJTÁR István: A 19. századi modern magyar állam- és jogrendszer alapjai. Európa - haladás - Magyarország. Budapest - Pécs 2003

KAYSER, Jacques: The Dreyfus Affair. New York 1931

KATZ, Jacob: Kifelé a gettóból. A zsidó emancipáció évszázada 1770-1870. Budapest 1995

KÉPES György: Az amerikai állammodell. Az Egyesült Államok alkotmányának alapelvei. Rubicon, 1997/8. sz. 38- 44.

Képviselőházi Napló. Az 1892. február 18-ra hirdetett országgyúlés nyomtatványai. Budapest 1892

vOn Kirchmann, J. H.: Der Kulturkampf in Preußen und sein Bedenken. Leipzig 1875

Kocher, Gernot: Die Reformen Josephs II. In: ReINALTER, Helmut (szerk.): Josephinismus als Aufgeklärter Absolutismus. Wien - Köln - Weimar, 125-161.

Kocher, Gernot: Szimbólumok és jelek a jogban. Történeti ikonográfia. Pécs 2008

KÓNYA Imre: Kálvinizmus és társadalomelmélet. Budapest 1979

KRABBE, Otto: Wider die gegenwärtige Richtung des Staatslebens im Verhältniß zur Kirche. Ein Zeugnis. Rostock 1873

LEISCHING, Peter: Kirche und Staat in den Rechtsordnungen Europas. Ein Überblick. Freiburg 1973

LEISCHING, Peter: Die römisch-katholische Kirche in Cisleithanien. In: WANDRUSZKA, Adam - URBANITSCH, Peter (szerk.): Die Habsburgermonarchie 1848-1918. Bank IV: Die Konfessionen. Wien 1995, 1-247.

LOCKE, John: Levél a vallási türelemről. Budapest 1992

LUDASSY Mária: Az ész államáig és tovább: XVIII. századi francia utópisták. Budapest 1979

LUTHER, Matin: Az egyház babiloni fogságáról szóló könyvecske. Felsőörs 2005

MAgnus, Philip: Gladstone: A Biography. London 1963

MaltBY, Judith: Prayer book and people in Elisabethan and early Stuart England. Cambridge 1998

MaYeR-Maly, Theo: Die Grundrechte des religiösen Lebens in der österreichischen Verfassungsgeschichte des 19. Jahrhunderts. In: Österreichisches Archiv für Kirchenrecht 1954/5. sz. 38-62.

MCConnel, James Buckley: Constitutional and Parliamentary History of the Methodist Episcopal Church. New York 1914

MCCLOSKEY, Robert G.: Az amerikai Legfelsőbb Bíróság. In: Alkotmánybíráskodás és alkotmányértelmezés. Budapest 1995, 35-41.

MCDOnelL, Ernest W.: The Beguines and Beghards in Medieval Culture. New Brunswick 1954

MCDOWALL, David: An Illustrated History of Britain. Longman 1989

MCGRATH, Alister E.: Kálvin. Budapest 1996

MEAD, Sidney E.: Das Christentum in Nordamerika. Glaube und Religionsfreiheit in vier Jahrhunderten. Göttingen 1987

MIKO, Norbert: Die katholische Kirche in Österreich-Ungarn um 1870 in der Berichterstattung des Wiener Nuntius. In: MetZler-ANDELBERG, Helmut J. (szerk.): Festschrift Karl Eder zum 70. Geburtstag. Innsbruck 1959, 211-222.

MORSEY, Rudolf: Wirtschaftlische und soziale Auswirkungen der Säkularisation in Deutschland. In: VIERHAUS, Rudolf - BotzenharT, Manfred (szerk.): Dauer und Wandel in der Geschichte. Festgabe für Kurt v. Raumer. Münster 1966, 361-383.

MurPHY, Walter F.: Congress and The Court. Chicago 1962, 7-69. 
NAGYNÉ SZEGVÁRI Katalin: Az elnök a kormányzatban az Egyesült Államok alkotmányos rendszerének kiépítése idején. In: MEZEY Barna (szerk.): Jogtörténeti előadások I. Budapest 1988, 22-40.

NAGYNÉ SZEGVÁRI Katalin: Az USA alkotmányos rendszerének kialalkulása. Jogászszövetségi értekezések I. Budapest 1989, 41-61.

OESCHEY, Rudolf: Montesquieu und die Verfassungen des deutschen Frühkonstitutionalismus. Zeitschrift für Staatswissenschaft 1944/104. sz. 361-389.

VON OESTFELD, M.: Die kirchenpolitische Reformgesetze Preußens. Breslau 1873

OWEN, Chadwick: A reformáció. Budapest 1998

PFEFFER, Leo: The Liberties of an American. Boston 1956

PIKART, Ebenhard: Die Rolle der Parteien im deutschen konstitutionellen System vor 1914. In: BÖCKENFÖRDE, ErnstWolfgang (szerk.): Moderne deutsche Verfassungsgeschichte (1815-1918). Köln 1972, 237-281.

DE PRESSEnsé, Edmond Dehault: L'Église et la Révolution française. Histoire des relations de l'église et de l'état de 1789 a 1814. Paris 1864

REINHOLD, Lorenz: Schwarzgelber Patriotismus. Der Katholizismus als Klammer der Hansburger Monarchie von 1848 bis 1918 . Wort und Wahrheit $1867 / 22$. sz. 372-377.

RICHTER, Karl Thomas: Staats- und Gesellschaftsrecht der französischen Revolution von 1789 bis 1804 I-II. Berlin 1865-1866

RÜTTIMANN, J.: Kirche und Staat in Nordamerika. Zürich 1871

SCHAMBECK, Herbert - Widder, Helmut - BergmanN, Marcus (szerk.): Dokumente zur Geschichte der Vereinigten Staaten von Amerika. Berlin 1993

STRAUSS, Herbert Arthur: Staat, Bürger, Mensch: Die Debatten der deutschen Nationalversammlung 1848/49 über die Grundrechte. Aarau 1947

TAINE, Hippolit Adolf: A jelenkori Franciaország alakulása I. Budapest 1889

Thompson, G. P.: Kirche und Staat in den Vereinigten Staaten von Nord-Amerika. Berlin 1873

Tresolini, Rocco J.: American Constitutional Law. New York 1965

WAHL, Reiner: Der preußische Verfassungskonflikt und das konstitutionelle System des Kaiserrreichs. In: BÖCKENFÖRDE, Ernst-Wolfgang (szerk.): Moderne deutsche Verfassungsgeschichte (1815-1918). Köln 1972, 171-194.

WALD, Kenneth D.: Religion and Politics in the United States. New York 1987

WEBER, Theodor: Staat und Kirche nach der Zeichnung und Absicht des Ultramontanismus. Breslau 1873

WERTHEIM, Karl: Wörterbuch des englischen Rechts. Berlin 1899

WuthnOw, Robert: Religion and the Voluntary Spirit in the United States: Mapping the Terrian. Faith and Philanthropy in America. San Francisco - Oxford 1990

ZELLER Árpád: A magyar egyházpolitika 1847-1894. A vallásszabadság, a polgári házasság, a katholikus autonómia, az alapok és alapítványok s egyéb egyházpolitikai kérdések történelmi fejlődése hazánkban I-II. Budapest 1894 